Louisiana State University

LSU Digital Commons

7-1999

\title{
The Impact of Accelerating Land-Use Change on the N-Cycle of Tropical Aquatic Ecosystems: Current Conditions and Projected Changes
}

\author{
J. A. Downing \\ M. McClain \\ R. Twilley \\ J. M. Melack \\ J. Elser
}

See next page for additional authors

Follow this and additional works at: https://digitalcommons.Isu.edu/oceanography_coastal_pubs

Digitart of the Oceanography Commons

Commons

Network

Logo 


\section{Authors}

J. A. Downing, M. McClain, R. Twilley, J. M. Melack, J. Elser, Nancy N. Rabalais, W. M. Lewis Jr., R. Eugene Turner, J. Corredor, D. Soto, A. Yanez Arancibia, J. A. Kopaska, and R. W. Howarth 


\title{
The impact of accelerating land-use change on the N-Cycle of tropical aquatic ecosystems: Current conditions and projected changes
}

\author{
J.A. DOWNING ${ }^{1}$, M. McCLAIN ${ }^{2}$, R. TWILLEY ${ }^{3}$, J.M. MELACK ${ }^{4}$,
} J. ELSER ${ }^{5}$, N.N. RABALAIS ${ }^{6}$, W.M. LEWIS, JR. ${ }^{7}$, R.E. TURNER ${ }^{8}$, J. CORREDOR ${ }^{9}$, D. SOTO ${ }^{10}$, A. YANEZ-ARANCIBIA ${ }^{11}$, J.A. KOPASKA $^{1}$ \& R.W. HOWARTH ${ }^{12}$

${ }^{1}$ Department of Animal Ecology, lowa State University, Ames, IA, U.S.A.; ${ }^{2} R S M A S-M G G$, University of Miami, Miami, FL, U.S.A.; ${ }^{3}$ Department of Biology, University of Southwestern Louisiana, Lafayette, LA, U.S.A.; ${ }^{4}$ Department of Ecology, Evolution and Marine Biology, University of California, Santa Barbara, CA, U.S.A.; ${ }^{5}$ Department of Zoology, Arizona State University, Tempe, AZ, U.S.A.; ' Louisiana Universities Marine Consortium, Chauvin, LA, U.S.A.; ${ }^{7}$ Center for Limnology, Cooperative Institute for Research in Environmental Sciences, University of Colorado, Boulder, CO, U.S.A.; ${ }^{8}$ Department of Oceanography and Coastal Sciences, Louisiana State University, Baton Rouge, LA, U.S.A.; ${ }^{9}$ Department of Marine Science, University of Puerto Rico, Mayaguez, PR; ${ }^{10}$ Facultad de Pesquierías y Oceanografia, Instituto de Ciencias Naturales y Exactas, Universidad Austral de Chile, Puerto Montt, Chile; ${ }^{11}$ Institute of Ecology A.C., Department of Coastal Resources, Xalapa, Veracruz, Mexico; ${ }^{12}$ Section of Ecology and Systematics, Cornell University, Ithaca, $N Y$, U.S.A.

Received 10 December 1998

Key words: estuaries, lakes, marine, nitrogen, phosphorus, rivers, streams, temperate, tropics

\begin{abstract}
Published data and analyses from temperate and tropical aquatic systems are used to summarize knowledge about the potential impact of land-use alteration on the nitrogen biogeochemistry of tropical aquatic ecosystems, identify important patterns and recommend key needs for research. The tropical $\mathrm{N}$-cycle is traced from pre-disturbance conditions through the phases of disturbance, highlighting major differences between tropical and temperate systems that might influence development strategies in the tropics. Analyses suggest that tropical freshwaters are more frequently $\mathrm{N}$-limited than temperate zones, while tropical marine systems may show more frequent $\mathrm{P}$ limitation. These analyses indicate that disturbances to pristine tropical lands will lead to greatly increased primary production in freshwaters and large changes in tropical freshwater communities. Increased freshwater nutrient flux will also lead to an expansion of the high production, $\mathrm{N}$ - and light-limited zones around river deltas, a switch from $\mathrm{P}$ - to N-limitation in calcareous marine systems, with large changes in the community composition of fragile mangrove and reef systems. Key information gaps are highlighted, including data on mechanisms of nutrient transport and atmospheric deposition in the tropics, nutrient and material retention capacities of tropical impoundments, and N/P coupling and stoichiometric impacts of nutrient supplies on tropical aquatic communities. The current base of biogeochemical data suggests that alterations in the
\end{abstract}


$\mathrm{N}$-cycle will have greater impacts on tropical aquatic ecosystems than those already observed in the temperate zone.

\section{Introduction}

Global nutrient cycles have been greatly altered by land-use changes over the last century. Studies in the temperate zone, for example, suggest that river export of nitrogen has increased by 3 - to 20 -fold in developed areas since industrialization (Howarth et al. 1996). Much of this increased load apparently results from human inputs of urban and agricultural waste (including sewage and fertilizers) and increased runoff due to cultivation and urbanization (Cole et al. 1993; Howarth 1998). In spite of the fact that we are only now beginning to understand the implications of these land-use changes for temperate freshwaters and seas, ecosystem alteration in the tropics is increasing even more rapidly than changes impacting temperate zones. The purpose of this analysis is to draw together information on temperate and tropical zone impacts on nutrient cycles to explore how differences among tropical and temperate zones may impact the trajectory of change in the coupling of land and water in the tropics.

Large-scale land-use changes are occurring in the tropical Americas, and these have important implications for the future of freshwater and marine ecosystems (Seeliger 1992; Yanez-Arancibia \& Lara-Dominguez 1998). Global rates of tropical deforestation are estimated at about 20 million ha $^{-1}$ $\mathrm{yr}^{-1}$ (Bruijnzeel 1996), and are rising especially rapidly in countries with high population and national debt (Rudel \& Roper 1996). Tropical lands are most frequently converted to agricultural or degraded landscapes (Houghton 1994; Skole et al. 1994), which are often less efficient sinks for carbon and other elements (Asner et al. 1997; Houghton 1994), have dramatically altered regional hydrology (Bruijnzeel 1996), and are subject to large losses of nutrient elements such as nitrogen (N) or phosphorus (P) (Ojima et al. 1994). It is likely that tropical aquatic ecosystems will frequently experience increased silt, water, and nutrient loads as land-use perturbations proceed.

Reactions of tropical aquatic ecosystems to large-scale alterations in nutrient fluxes are less well documented than those demonstrated at higher latitudes. In temperate zones, changes in land-use have caused increases in nutrient loading (especially $\mathrm{P}$ ) to lakes and rivers, resulting in wide-spread alterations of water quality (Cooke et al. 1993) and losses of resourceproductive ecosystems (Ross 1997). Increased nutrient loads (especially N) carried by rivers (Cole et al. 1993) have also increased nutrient inputs to many of the world's great coastal zones (Meybeck 1982; Meybeck 1998; 
Turner \& Rabalais 1991), accelerated coastal hypoxia (Diaz \& Rosenberg 1995; Justic et al. 1993), and impacted economically important estuarine and coastal fisheries (Diaz et al. 1992; Yanez-Arancibia 1998). Although freshwater and marine fisheries and aquaculture yields are important protein sources in developing coastal nations (Bailey et al. 1996; Yanez-Arancibia 1985), we know relatively little about the potential impact of land-use alteration on the large scale biogeochemistry of tropical aquatic ecosystems (Twilley \& Day 1998).

The purposes of this article are to use information on tropical and temperate ecosystem alterations to summarize the current evidence concerning this issue, identify probable patterns of change, and recommend key directions for future research. We trace the tropical $\mathrm{N}$-cycle from pre-disturbance conditions, through the likely phases of disturbance and highlight some of the implications of differences between tropical and temperate systems that might influence the trajectory of disturbance in the tropics. Because the outcome of perturbation of the $\mathrm{N}$-cycle will be determined by its coupling or decoupling with changes in the P-cycle, we also explore the likely impacts of altered N:P ratios on aquatic ecosystems.

\section{Pre-disturbance N-export: Influence of vegetation, precipitation, and latitude}

The effects of altered $\mathrm{N}$ cycling in tropical ecosystems can be understood most easily in the context of $\mathrm{N}$ dynamics in undisturbed or minimally disturbed tropical ecosystems. The predisturbance $\mathrm{N}$ concentrations and runoff fluxes depend upon water runoff rates and vegetative cover which differ between tropical and temperate latitudes. Background $\mathrm{N}$-export rates of watersheds where disturbance through atmospheric deposition and landscape change is minimal average about $5 \mathrm{~kg} \mathrm{ha}^{-1} \mathrm{yr}^{-1}$, of which about $65 \%$ is in the particulate or dissolved organic form, while $35 \%$ is dissolved inorganic $\mathrm{N}$ (Lewis et al. this volume). Nitrogen export rates of undisturbed tropical watersheds are about five-fold greater than those seen in temperate regions, given similar rates of runoff (Figure 1). The principal exceptions to this trend are the Rio Negro, a black-water tropical river carrying an exceptionally low load of suspended particulate matter and a very low $\mathrm{N}$-export rate, and the Mackenzie and Lena Rivers, which are large rivers carrying large sediment loads at high latitudes. Predisturbance, low-sediment river systems like the Rio Negro and most temperate pristine rivers follow one relationship between water runoff and $\mathrm{N}$-export, while most tropical rivers and very large highlatitude rivers follow a different, much higher, relationship (Figure 1). This 


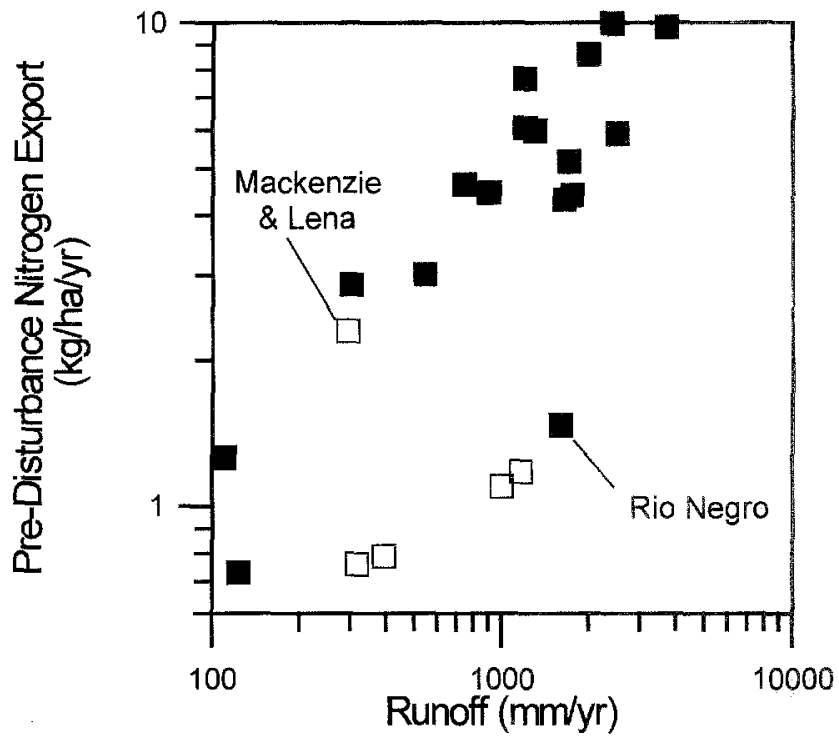

Figure 1. Relationship of pre-disturbance nitrogen export rate to the hydraulic runoif in tropical rivers ( $\mathbf{\square}$ Lewis et al., this volume) and estimates of pristine nitrogen export in the temperate zone and arctic ( $\square$ Howarth et al. 1996). The Mackenzie and Lena Rivers are sediment laden arctic rivers, while the Rio Negro is a tropical river with very low suspended sediment load.

can be seen even more clearly in Figure 2, where predisturbance $\mathrm{N}$ export rates are plotted against the average latitude of the river.

Pristine tropical landscapes may have relatively high $\mathrm{N}$ loss rates which result from high rates of $\mathrm{N}$ fixation and the general lack of $\mathrm{N}$ limitation in tropical terrestrial ecosystems (Martinelli et al., this volume; Vitousek 1984; Vitousek \& Howarth 1991). It is likely, therefore, that predisturbance tropical watersheds conserve less $\mathrm{N}$ and allow more to be fixed, so that $\mathrm{N}$ concentrations exported from disturbed tropical watersheds may be even greater than those seen in temperate systems. This conclusion is consistent with high concentrations of inorganic $\mathrm{N}$ in tropical rivers that are indicative of weak $\mathrm{N}$ retention by tropical moist forests (Lewis et al. 1995). These data suggest that anthropogenic impacts of perturbation to tropical N-cycles may be set against a backdrop of high $\mathrm{N}$ transport of tropical aquatic systems.

\section{Projected changes in atmospheric $\mathbf{N}$-loading of tropical waters}

If tropical patterns of urbanization, industrialization, and agricultural development proceed as they have in temperate zones, development in the tropics will impact both the background atmospheric deposition rates of $\mathrm{N}$ and the 


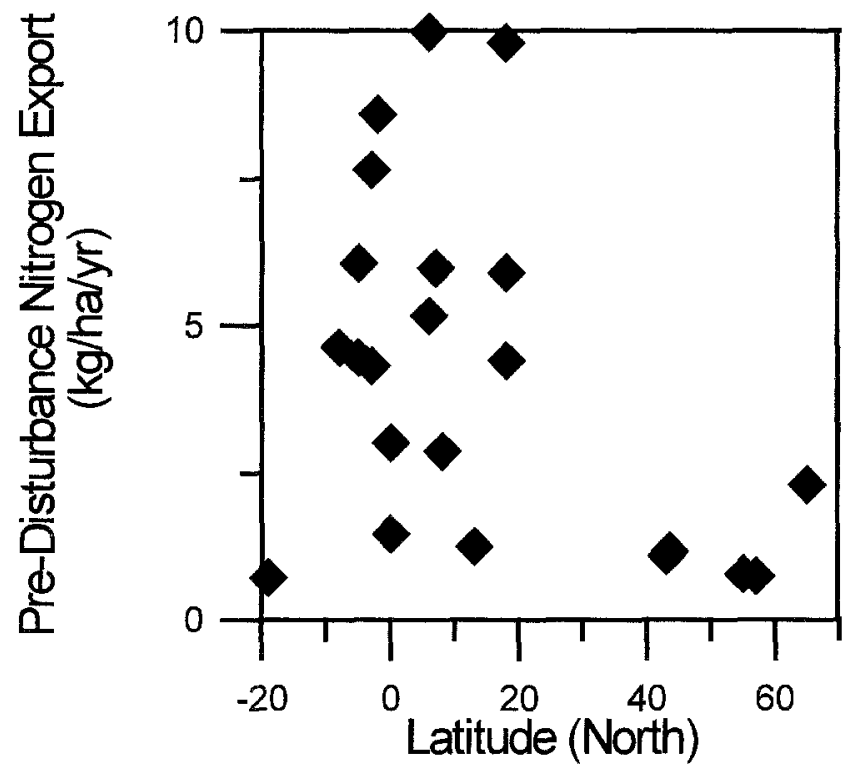

Figure 2. Geographical distribution of pre-disturbance nitrogen export rates. Data are from the sources cited in Figure 1.

rates of processing and export to aquatic systems. For example, fire mobilizes large amounts of $\mathrm{N}$ not only during the agricultural development phase but also after conversion of tropical landscapes (e.g., Lewis 1981). Pre-industrial and modern atmospheric inputs of nitrogen to a wide variety of catchments over a range of latitudes have been estimated elsewhere (Howarth et al. 1996) following the models of Prospero et al. (1996). Pre-industrial background deposition rates probably drove pre-industrial $\mathrm{N}$-export by rivers, because measured nitrogen export rates in the temperate zone are generally about the same as the model estimated pre-industrial atmospheric $\mathrm{N}$ input (Figure 3). In the tropics, $\mathrm{N}$ export exceeds likely rates of deposition by a considerable amount because of $\mathrm{N}$ fixation by terrestrial vegetation. Atmospheric deposition rates are likely to increase in developing areas of tropical Asia and America as they have in industrialized parts of the temperate zone (Galloway 1989; Galloway et al. 1994).

Although industrialization has not yet occurred on as broad a scale in the tropics as it has in the temperate zone, probable changes in $\mathrm{N}$-export of tropical ecosystems can be inferred from modeled values of pre- and postindustrial deposition rates across a range of latitudes (Figure 3). Pre-industrial $\mathrm{N}$ deposition in the tropics is calculated to be about twice that of temperate sites, probably because natural sources of volatilization of $\mathrm{N}$ to the atmosphere are greater in tropical N-rich ecosystems. Modern N-deposition in the 


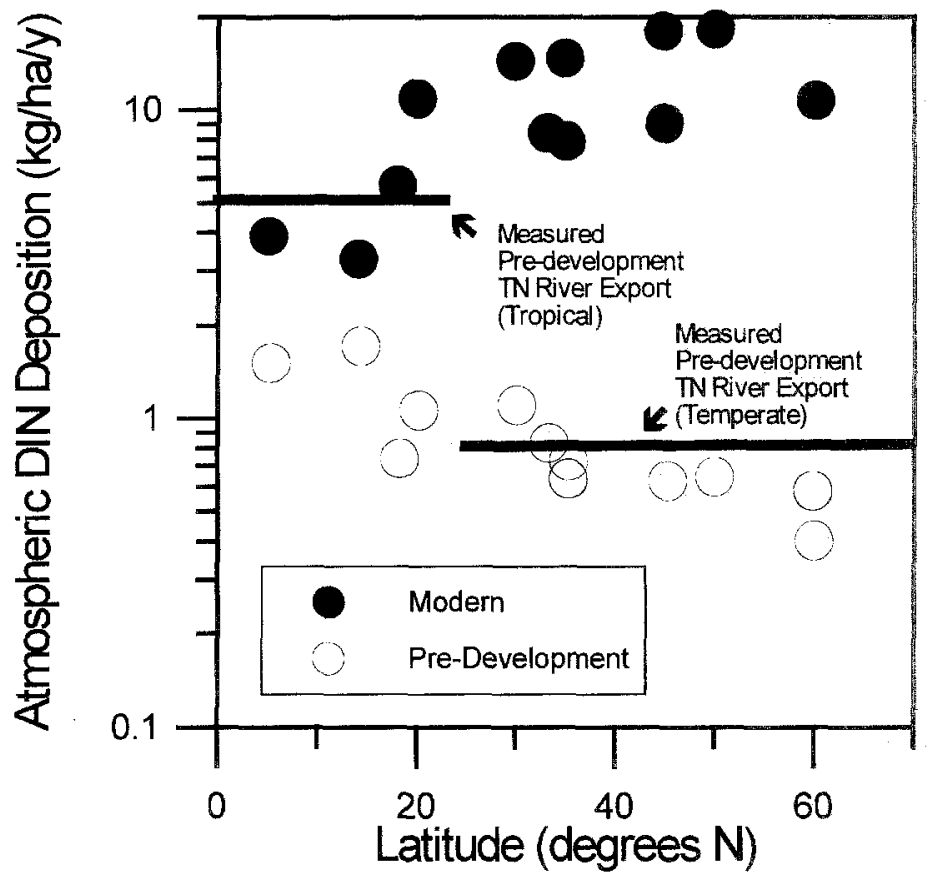

Figure 3. Relationship latitude and model-predicted pre-development and modern atmospheric $\mathrm{NO}_{x}-\mathrm{N}$ and $\mathrm{NH}_{y}-\mathrm{N}$ (summed) atmospheric deposition to latitude. Data on atmospheric deposition are from Prospero et al. (1996) for the large watersheds analyzed by Howarth et al. (1996). Pre-development, tropical total nitrogen export line is the average from Lewis et al. (this volume) and temperate pre-development total nitrogen export is the average from Howarth et al. (1996).

temperate zone, however, has probably increased more than 10-fold, while relatively undisturbed tropical systems have $\mathrm{N}$-deposition rates very close to pre-industrial rates (see also Soto \& Stockner 1996). If similar patterns of development and industrialization are followed in the tropics, it is likely that atmospheric $\mathrm{N}$-deposition will increase more radically, such that tropical $\mathrm{N}$-deposition may move to even higher levels than the rates currently found in industrialized temperate catchments. $\mathrm{N}$ export to tropical waters may be proportionately greater in the tropics than in the temperate zone because $\mathrm{N}$ is, in general, not as frequently limiting to the growth of tropical vegetation and thus not retained as effectively by vegetation in tropical terrestrial systems (Mattson et al., this volume; Vitousek \& Howarth 1991).

The inference that $\mathrm{N}$ throughput will be greater in disturbed, industrialized tropical systems than in temperate zones assumes that the sources of presentday tropical atmospheric $\mathrm{N}$ deposition are not diminished by disturbance. If, for example, the source of atmospheric $\mathrm{N}$ deposition is currently rede- 
position of forest-fixed $\mathrm{N}$, and forest biomass is reduced substantially, then deforestation may result in decreased rates of $\mathrm{N}$ deposition, although contrary examples have been documented (Lewis 1981). If forests are converted to pasture, less $\mathrm{N}$ may be released to the atmosphere (Neill et al. 1995). Further, if terrestrial nitrogen fixation is fueling high background $N$ export rates from tropical watersheds, increased atmospheric $\mathrm{N}$ deposition may reduce this fixation, and thus only a slight change in $\mathrm{N}$ release may be observed from these watersheds. In general, however, available data suggest that disturbed tropical landscapes will often have greatly increased rates of $\mathrm{N}$ deposition.

\section{Changes in the partitioning of nitrogen in atmospheric deposition and riverine transport}

The partitioning of nitrogen in atmospheric deposition and fluxes in rivers may also change with altered land-use. Models suggest that the American tropics currently receive about a 2:1 mix of $\mathrm{NO}_{y}$ and $\mathrm{NH}_{x}$ in atmospheric deposition (Prospero et al. 1996), a ratio which is very close to that probably received by tropical ecosystems (Figure 4 ) in the absence of industrialization. If mechanisms of release and deposition are altered in the tropics as they have been with temperate industrialization, the proportion of $\mathrm{NO}_{y}$ relative to $\mathrm{NH}_{x}$ deposition should increase so that $\mathrm{NO}_{y}$ might become the more dominant source of inorganic nitrogen in tropical precipitation (Figure 4). On the other hand, expanding agriculture might lead to greater $\mathrm{NH}_{x}$ deposition due to volatilization of anhydrous ammonia. An analysis of heavily developed temperate regions shows that $\mathrm{NO}_{y}$ deposition dominates in some systems, while $\mathrm{NH}_{x}$ dominates in others (Howarth et al. 1996; Howarth 1998). Presumably either of these forms could become dominant in the tropical regions as they become more developed, depending upon the balance between industrial/urban and agricultural development.

Tropical rivers and streams are often relatively rich in DON $(\approx 35 \%$ of total N, Lewis et al., this volume; McDowell \& Asbury 1994), as is true for undisturbed temperate systems (Hedin et al. 1995; Vitousek et al. 1997). In temperate regions, increased inputs of nitrogen from human activity result in a proportionally greater riverine export of nitrogen in the form of nitrate (Jaworski et al. 1997). This is true whether the major inputs of nitrogen are from agriculture or atmospheric deposition, and whether atmospheric deposition is dominated by $\mathrm{NO}_{y}$ or $\mathrm{NH}_{x}$ (Vitousek et al. 1997). An analysis of nitrate fluxes from the largest rivers in the world suggests that this is also true for disturbed tropical watersheds, as nitrate fluxes are correlated with watershed population densities in both temperate and tropical regions (Cole et al. 1993; Peierls et al. 1991). 


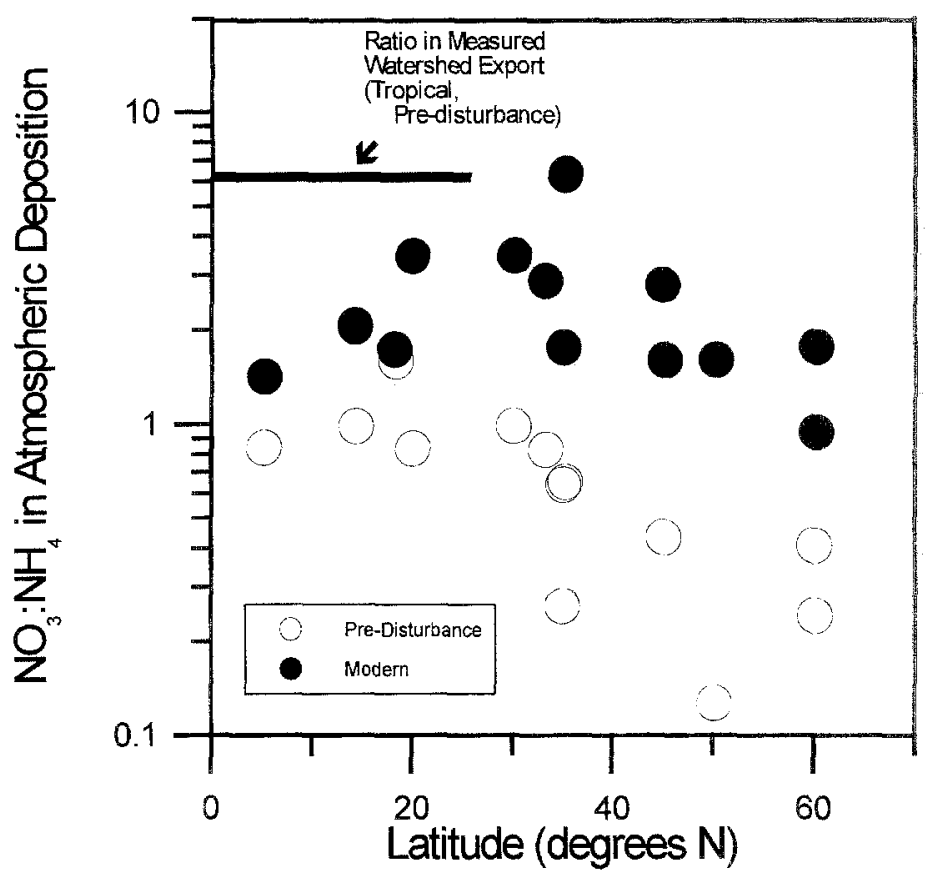

Figure 4. Latitudinal trend in the atmospheric $\mathrm{NO}_{x}-\mathrm{N}: \mathrm{NH}_{y}-\mathrm{N}$ ratio from pre-disturbance and modern estimates. Calculations below the sources listed in Figure 3. The solid line indicates the average ratio $\mathrm{NO}_{x}-\mathrm{N}: \mathrm{NH}_{y}-\mathrm{N}$ in water exported from pre-disturbance tropical watersheds (Lewis et al., this volume).

\section{The trajectory of land development and its effects on nitrogen export to tropical waters}

Development in tropical and temperate zones typically proceeds through several stages of development, land-use change, urbanization, and industrialization. Generally, grasslands (Garrity \& Agustin 1995) then forests (Murdiyarso \& Wasrin 1995) are converted to agricultural production, followed by movement of rural populations to urban areas (Hall \& Hall 1993), then increased industrialization and land-use changes (e.g., water extraction, urban sprawl) necessitated by growing urban centers. This has already been established as a consistent pattern of land-use transformation in the tropics (Behrens et al. 1994; Brondizio et al. 1993; Eastwood \& Pollard 1992; Sussman et al. 1994).

The development of tropical landscapes is likely to result in substantially higher $\mathrm{N}$ export as a result of increased atmospheric deposition and increased agriculture. Lessons learned in the temperate zone suggest that the phases of progressive intensification of human development gradually reduce ecosys- 
tem complexity. Examples of this progression are found in the tropics, where vast areas of native forest are being cleared and replaced by managed systems ranging from pastures and agricultural fields to urban and industrial centers. Evidence that this trajectory is proceeding in the tropical Americas is that forest and woodland coverage has decreased by $4.1 \%$, pasture and croplands have increased $3 \%$, while $4.7 \%$ of the population has moved to urban centers over the last decade (World Resource Institute 1996). Our present knowledge of controls on $\mathrm{N}$ cycling in disturbed temperate systems and data collected in a variety of individual tropical watersheds allow some general predictions to be made on likely changes in $\mathrm{N}$ export from tropical landscapes subjected to progressive phases of development.

The progression of tropical development from pristine to highly altered (e.g. intensive agriculture, urban/industrial systems) is likely to result in a predictable sequence of changes to $\mathrm{N}$ exports. Normally this would be characterized by (1) an initial pulse in $\mathrm{N}$ exports via leaching and erosion upon cutting of mature forests and other vegetation, (2) a second pulse in $\mathrm{N}$ exports via leaching and erosion upon burning, (3) a continual increase in $\mathrm{N}$ exports as anthropogenic $\mathrm{N}$ inputs to the system override natural cycles, (4) a decrease in $\mathrm{N}$ fluxes as large-scale water management systems are built to hold water behind dams for irrigation or other uses, and (5) an eventual leveling off as anthropogenic inputs and outputs establish a new equilibrium. Although other trajectories of development might occur, this hypothesis and the progression of events it implies are illustrated in Figure 5 and are described and justified in detail below.

Phase 1 - Deforestation - Rapid forest losses are typical of all phases of disturbance in developing tropical nations (e.g., Salati et al. 1991). In warm, humid tropical climates, the labile components of cut forest slash quickly decompose and rains leach newly remineralized nitrogen into the soil column (Williams et al. 1997a, b). As the root systems of the previous forest begin to die and decompose, less leached nitrogen is absorbed, and nitrate levels in infiltrating waters remain elevated. When the water table rises, this pulse of nitrate moves laterally toward the streamside where the fate of nitrate is strongly influenced by the condition of streamside soils and vegetation. If the riparian zone remains forested and intact, the pulse of nitrate is diminished via denitrification in water-logged, organic rich, and anoxic streamside soils (McClain et al. 1994). Where the riparian zone has also been cut, the streamside buffering capacity is reduced, and higher levels of dissolved nitrogen will enter the stream via groundwater baseflow. Baseflow itself increases because of reduced plant uptake of infiltrating rainwater (Bruijnzeel 1990). After the pulse of nutrient is received by lentic freshwaters, denitrification is likely very rapid because anoxic lakes or lakes with anoxic hypolimnia are common 


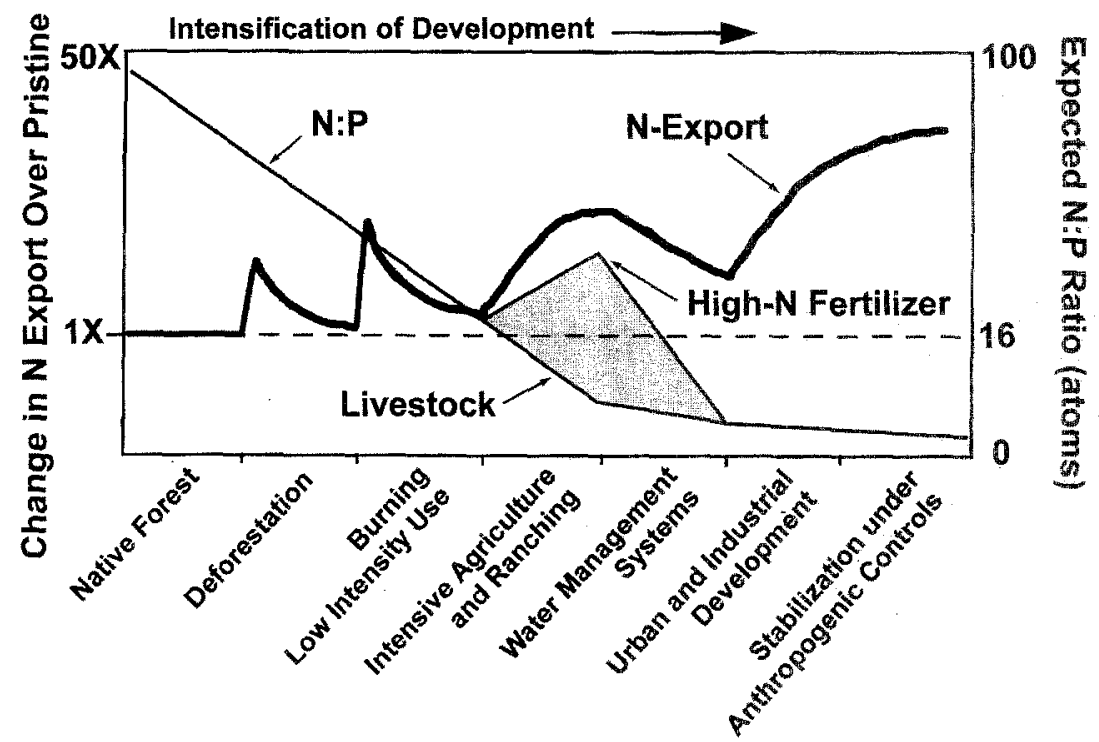

Figure 5. Expected trend in nitrogen loading and the N:P ratio of tropical aquatic systems as tropical development proceeds (see text).

in the tropics (e.g., Saijo et al. 1997; Salati et al. 1982; Tundisi 1981; c.f. Gonzalez et al. 1991) at least in areas where hydraulic budgets have not been greatly augmented (Furch \& Junk 1993; c.f. Villar et al. 1996).

Erosion of particulate $\mathrm{N}$ also increases following deforestation, as destruction of soil structure leads to decreased infiltration capacities and greater overland flow (Bruijnzeel 1990). This condition can be exacerbated by higher rainfall amounts at the soil surface when canopy interception is reduced. Erosion and hydraulic loads to streams are also increased in response to the building of roads into deforested areas. The erosive inputs of particulate $\mathbf{N}$ to nearby streams are strongly dependent on the buffering capacity of the riparian zone. Labile forms of organic matter will eventually be exhausted, but erosive inputs may remain high. Increased hydraulic loads from cleared land can decrease denitrification because of augmented hydraulic flushing (Quirós 1990; Villar et al. 1996) while increased erosion can decrease transparency of tropical waters so much that nutrient retention is significantly reduced (Tundisi et al. 1981).

Phase 2-Burning and Low-Intensity Use - After forest clearing, slash is often burned to clear debris, thus releasing organically-bound nutrient stocks to the soil. Burning transfers as much as $96 \%$ of organic $\mathrm{N}$ and $>40 \%$ of the $P$ to the atmosphere (Hölscher et al. 1997; Kauffman et al. 1995), but these nutrients will probably be redeposited within tropical ecosystems (Victoria et al. 1991). When slash is physically removed from the site, the losses of 
all nutrients are significant (Fernandez et al. 1997). Burning slash leads to a second pulse of dissolved $\mathrm{N}$ in subsurface flow, atmospheric redeposition, and a reinvigoration of erosion (Juo \& Manu 1996). Part of the increase in nitrate is to balance the additional positive charge brought by significant increases in the influx of base cations after burning. Again, the presence or absence of an intact riparian zone can strongly influence the degree to which a particular stream is impacted by burning of the upland forest surrounding it.

Lesack and Melack (1996) have suggested two different scenarios for the impact of development on precipitation chemistry and nutrient balances of tropical forests. In one, the conversion of forest to pasture or cropland could result in less material entrained into the atmosphere by convection, which would in turn reduce the flux of recycled nutrients to the remaining islands of forest. The reduced amount of rainfall predicted by Shukla et al. (1990) after deforestation of the Amazon would exacerbate this scenario. Alternatively, conversion of forest to pasture or cropland could result in an increase in dust in the atmosphere, with more material entrained into the atmosphere than from the former forest. Because repeated burning may be used to control secondary vegetation after conversion, emissions of some chemical species could be further enhanced relative to the uncut forest. Hence, the flux of recycled nutrients to remnants of forest might increase as the surrounding landscape is converted from forest to pasture or cropland.

Land subjected to slash and burn practices is usually developed as pastures or small-scale agricultural fields (Brondizio et al. 1994). Where these agricultural practices remain at low intensity (i.e. without application of fertilizers), the exports of dissolved nitrogen should again tend to decrease after the initial pulse, reflecting a gradual depletion in $\mathrm{N}$ stocks. The slash-and-burn cycle may be repeated multiple times over several years. Without fertilization of the infertile soils dominating the tropics, the nutrient status of tropical soils will diminish until agricultural land-use must be abandoned. In cases of intensive agriculture, fertilizer use on infertile tropical lands may eventually exceed rates of application in temperate systems to sustain economic levels of production. Therefore, depleted soils and associated loss of inorganic fertilizers may be more acute in tropical agriculture than temperate zones.

Phase 3 - Intensive Agriculture and Ranching - As land-use intensifies, anthropogenic sources and sinks of $\mathrm{N}$ should become the dominant $\mathrm{N}$ fluxes. Nitrogen fertilizers are often applied at rates greater than plants' requirements and there is nearly always a significant excess of nitrogen beyond that removed from agricultural fields as harvested crops (Hölscher et al. 1997; Keftasa 1994; Chowdhury \& Rosario 1993). The rest of the nitrogen is stored in the soil, leached in surface runoff or in groundwater (Deare et al. 1995), or volatilized to the atmosphere. The amount of nitrogen leached from agri- 
cultural fields is greater in tilled fields than in pastures (Neill et al. 1995) and is greater in sandy soils than in clayey soils. When expressed as a percentage of nitrogen added in fertilizer, the nitrogen leaching from agricultural soils in surface and groundwaters varies from 28\% to $85 \%$ (Hölscher et al. 1997; Kühne 1993; Poss \& Saragoni 1992). Even when agricultural soils are not fertilized, they leach more nitrogen than do forests, perhaps due to lowered evapotranspiration and greater water runoff (Uhl \& Jordan 1984; Seyfried \& Rao 1991; Sur et al. 1992; Vitousek \& Melillo 1979). When runoff water from tropical agricultural systems runs through wetlands before reaching streams, a large proportion of the leached nitrogen can be denitrified (Arheimer \& Wittgren 1994; Peterjohn \& Correll 1984; Pinay \& Decamps 1988; Vought et al. 1994). Very high rates of denitrification may occur in the hyporheic zones of tropical streams (Sjodin et al. 1997). In the absence of substantial wetland buffer strips or hyporheic denitrification, however, levels of nitrate in streams may rise to levels well above those required by freshwater biota, so aquatic communities may be greatly altered by intensive agriculture (Pedrozo \& Bonetto 1989). Physical practices related to intensive land cultivation also increase erosion and, therefore, further augment exports of particulate $\mathrm{N}$.

In addition to nitrogen leaching from agricultural fields, agriculture can contribute to nitrogen mobilization in the landscape through increased volatilization to the atmosphere and subsequent deposition, particularly of $\mathrm{NH}_{x}$. Howarth (1998) has demonstrated that at the scale of large regions, $\mathbf{N H}_{x}$ deposition is strongly correlated with riverine export of nitrogen, and that $\mathrm{NH}_{x}$ deposition appears to be a strong surrogate measure of the leakiness of "surplus" nitrogen from agricultural systems.

Phase 4 - Water Management Systems - Reservoir development often accompanies the initiation of large-scale intensive agriculture (MatsumuraTundisi et al. 1981). It is also associated with increasing urban populations, industrialization, and hydroelectric power needs in the tropics (Tundisi 1981, 1994). The impact of reservoir development should generally lead to a decrease of nutrient exports from catchments (Bonetto et al. 1994; Pedrozo et al. 1992; Tundisi \& Matsumura-Tundisi 1981; Vorosmarty et al. 1997). Reservoirs increase water residence times, thus allowing greater biotic uptake by aquatic vegetation, and the establishment of anoxic bottom water conditions that promote denitrification, acting to reduce exports of $\mathrm{N}$ to downstream receiving waters. Nutrient retention may be extremely dynamic, however, since some tropical lakes apparently retain nutrients during periods of low water but release them during the rainy season (Furch \& Junk 1993). Experience in temperate ecosystems (Fleisher \& Stibe 1991) suggests that $N$ retention in lakes and natural wetlands varies between about $10 \%$ and $90 \%$ (including biotic uptake, sedimentation, and denitrification), depending upon 


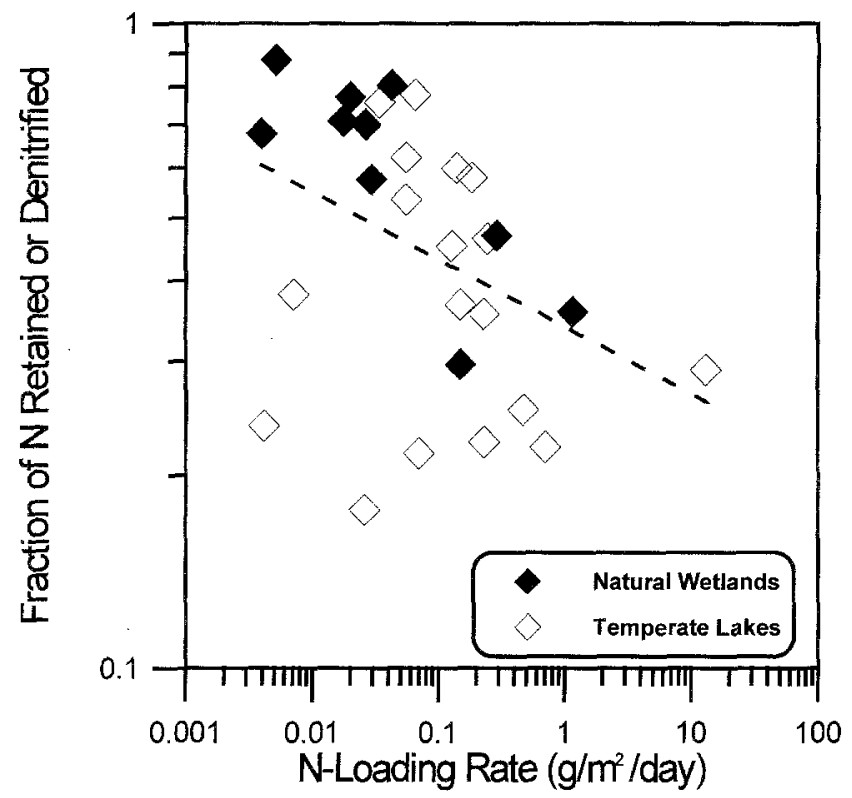

Figure 6. Relationship between nitrogen "retention" (including denitrification losses) and nitrogen loading rate in temperate zone lakes and ponds (Fleisher \& Stibe 1991). The dashed line indicates the least squares regression relationship between the logarithms of the two variables $(n=28, r=0.39, p<0.05)$.

the hydraulic and biotic characteristics of the water body (Howarth 1998). Wetlands have very high rates of $\mathrm{N}$ retention (Figure 6), but $\mathrm{N}$ retention decreases as $\mathrm{N}$-loading rises above about $0.1 \mathrm{~g} \mathrm{~m}^{-2} \mathrm{day}^{-1}$ (Figure 6). Although the data plotted in Fig. 6 may be somewhat optimistic compared to riverine $\mathrm{N}$ retention (Day \& Kemp 1985), temperate data suggest that impoundments and wetlands can retain large amounts of $\mathrm{N}$, but that their $\mathrm{N}$ removal efficiency will decrease as $\mathrm{N}$-loading rises. The impact of tropical impoundments on $\mathrm{N}$ loads may be less than impoundments in temperate systems, however, if $\mathrm{N}$ fixation rates in tropical waters are very high, or if high turbidity hampers biotic nutrient uptake (e.g., Arcifa et al. 1981b).

Phase 5 - Major Urban and Industrial Development - Within major urban and industrial areas, natural cycles of $\mathrm{N}$ are nearly completely overwhelmed by anthropogenic sources. High inputs of human waste and effluent from industrial activities enrich rivers with organic and inorganic nitrogen. Where light or turbulence do not renew oxygen, river waters may become hypoxic and the river biota may shift toward species tolerant of low oxygen conditions. Even the nutrient retention capacity of impoundments may be hampered because of very high rates of cultural eutrophication that accompanies urbanization in the tropics (Tundisi 1987; Arcifa et al. 1981a). 
Without remedial measures, river exports of $\mathrm{N}$ will increase in proportion to anthropogenic inputs, unless denitrification is very rapid.

In large tropical river basins, several of these phases are likely to be active simultaneously in the landscape. Consequently, the downstream effects of each will be integrated into a single export to coastal waters. The magnitude of this integrated export will depend partially upon the proportion of the basin subject to each phase of development.

\section{Impacts of tropical development on the relative availability of $\mathrm{N}$ and $\mathrm{P}$}

It is now well known that $\mathrm{N}$, $\mathrm{P}$, or other nutrients (Downing 1997) can limit primary production in freshwater and marine systems, and that the limiting nutrient is determined by the relative availability of ambient $\mathrm{N}, \mathrm{P}$ and other essential nutrients. Therefore, understanding the expected changes in ecosystem function due to alteration of $\mathrm{N}$ cycling must include a consideration of accompanying alterations in other important nutrients, especially P. In fact, if the N:P ratios of receiving waters are high (i.e., higher than $16: 1$ in atomic units; Redfield 1934), the impacts of enhanced $\mathrm{N}$-export may be low because $P$ will be the principal element limiting freshwater production.

It is likely that $\mathrm{N}: \mathrm{P}$ ratios in aquatic ecosystems will vary along a predictable trajectory across the phases of development presented above. Background N:P ratios tend to be very high in waters exported from undisturbed tropical terrains (Bruijnzeel 1991; Williams \& Melack 1997), often higher than 100:1 (as atoms; Table 1). In minimally impacted tropical freshwaters, denitrification is quite rapid (Salati et al. 1982; Saijo et al. 1997) and warm, anoxic waters keep P mobile (Furch \& Junk 1993), so N:P ratios are typically quite low (Bonetto et al. 1994; Pedrozo \& Bonetto 1989; Pedrozo et al. 1992; Rai \& Hill 1980). In some tropical regions, however, oxic conditions and waters rich in iron and dissolved organic matter may reduce $P$ concentrations keeping N:P high (Gonzalez et al. 1991; Tundisi et al. 1991).

As forests are cleared, the $\mathrm{N}: \mathrm{P}$ in exported waters will decrease. Storm related erosion, common in deforested areas, yields significantly lower $\mathrm{N}: \mathrm{P}$ due primarily to increased transport of particulate matter containing relatively high concentrations of $\mathrm{P}$. Burning volatilizes more of the $\mathrm{N}$ contained in biomass than the $\mathrm{P}$ (Hölscher et al. 1997; Kauffmann et al. 1995). The $\mathrm{N}: \mathrm{P}$ ratio should therefore decline steadily throughout the burning phase of deforestation (Figure 5) unless most volatilized $\mathrm{N}$ is redeposited locally. Agricultural development can have different impacts on $\mathrm{N}: \mathrm{P}$ ratios, because grain cultivation (e.g., maize) often uses large nitrogen amendments (e.g., anhydrous ammonia), which leads to high $\mathrm{N}: \mathrm{P}$ ratios of runoff, while animal husbandry leads to lower $\mathrm{N}: \mathrm{P}$ ratios (e.g., $<20$ ) characteristic of effluents 
Table 1. Data represent the N:P ratios (molar) found in various known aquatic nutrient sources or in water fluxes leaving different land-uses.

\begin{tabular}{lll}
\hline Source & N:P (atomic) & Reference \\
\hline Unfertilized fields & 547 & Loehr 1974 \\
Soils, medium fertility & 166 & Vollenweider 1968 \\
Forested areas & 157 & Loehr 1974 \\
Rural lands & 135 & Loehr 1974 \\
Soils, fertile & 74 & Vollenweider 1968 \\
Tropical forests & 52 & Loehr 1974 \\
Agricultural watersheds & 44 & Uttormark et al. 1974 \\
Forest export & 38 & Beaulac \& Reckhow 1982 \\
Mixed agriculture & 35 & Beaulac \& Reckhow 1983 \\
Sewage effluent & 22 & Golterman 1975 \\
Cattle manure seepage & 20 & Loehr 1974 \\
Non-row crop export & 18 & Beaulac \& Reckhow 1982 \\
Fertilizer, average & 17 & Turner \& Rabalais 1991 \\
Redfield ratio & 16 & Redfield 1934; Harris 1986 \\
Feedlot runoff & 14 & Loehr 1974 \\
Pastureland runoff & 13 & Beaulac \& Reckhow 1982 \\
Urban stormwater & 13 & Loehr 1974 \\
Sewage & 12 & Vollenweider 1968 \\
Urban runoff & 11 & Beaulac \& Reckhow 1982 \\
Pastureland runoff & 11 & Loehr 1974 \\
Urban runoff & 10 & Uttormark et al. 1974 \\
Row crop export & 9 & Beaulac \& Reckhow 1982 \\
Sewage & 6 & Vallentyne 1974 \\
Septic tank effluent & 6 & Brandes et al. 1974 \\
Bird feces & 2 & Portnoy 1990 \\
\hline & & \\
& & \\
\hline
\end{tabular}

from manures (Table 1). The N:P ratio should further be reduced as nutrientenriched waters pass through impoundments, especially if they are deep and have long water-residence times, because denitrification occurs at the sediment-water boundary in reservoirs and soluble $P$ is released in anoxic sediments. Some upward pressure may be put on N:P, however, if land clearing leads to drastically altered hydrology that flushes normally anoxic waters where denitrification was naturally common. Urban and industrial sewage has a low N:P ratio (Downing \& McCauley 1992), so long-term trends in heavily impacted tropical regions should stabilize at low N:P ratios typical 
of urbanized conditions. Thus, not only should nutrient export change with land-use, but nutrient supply ratios are likely to decline as development of tropical watersheds proceeds.

\section{Tropical freshwater responses to $\mathrm{N}$ - and P-loading}

The relative importance of $\mathrm{N}$ or $\mathrm{P}$ as a limiting nutrient depends not only upon their ratio in the inputs, but on several internal processes (Howarth 1988). These internal processes include recycling within the water column, sedimentation, resuspension or release from the bottom, and nitrogen fixation. Hence, proper evaluation of freshwater responses to altered N-loading requires a comparative analysis of how these processes alter nutrient cycling and availability.

As indicated above, disturbance will likely lead to a decrease in ratios of available $\mathrm{N}$ and $\mathrm{P}$, although assembling a data set that is geographically representative of loadings to tropical lakes and streams is problematic. Different $\mathrm{N}$ and $\mathrm{P}$ fractions (i.e. dissolved inorganic, total dissolved, dissolved organic, particulate, or total) have been measured in various systems, and it is unclear whether the measured fractions are available for biological uptake, or whether sampling or analytical problems have yielded a clear view of tropical nutrient fluxes. Phrasing the hypothesis as a comparison between tropical and temperate regions may also confound the analysis, because the variability arising from land-use patterns could override that arising from geographical differences. Hence, the data we have chosen to make such comparisons below are from the least disturbed catchments possible.

The N:P ratios of total $\mathrm{N}$ and $\mathrm{P}$ fluxes in rivers draining into the North Atlantic (Table 2) supports the hypothesis that tropical freshwaters should generally be more sensitive to $\mathrm{N}$-loading than temperate ones because the $\mathrm{N}: \mathrm{P}$ ratios in tropical water flowing from large tropical drainage basins are at, or below, the Redfield atomic ratio (ca. 16), while the ratios in water leaving large temperate American and European basins (even those in undeveloped areas) are generally above 16 (Søballe \& Kimmel 1987). Another approach is to examine yields of $\mathrm{N}$ and $\mathrm{P}$ from different land-uses. Based on North American data, as the dominant land-use changes from forests or mixed agriculture to pastures, crops, and finally to urban uses, total $\mathrm{N}$ to total $\mathrm{P}$ export shifts from values above atomic N:P ratios of 16 to values near or below 16 (Table 1). Moreover, Billen et al. (1991) found that total dissolved nutrient concentrations increased and dissolved N:P ratios decreased in a set of temperate catchments with land-use ranging from forested to agricultural to urbanized. Further, Peierls et al. (1991) reported strong statistical evidence for increased nitrate concentrations in rivers worldwide as a function of 
Table 2. Regional $\mathrm{N}$ to $\mathrm{P}$ atomic ratios (Howarth et al. 1996) expressed as ratios of total $\mathrm{N}$ fluxes to total $\mathrm{P}$ fluxes. Data are for river systems flowing into the North Atlantic Ocean.

\begin{tabular}{ll}
\hline River/ Region & N:P Ratio \\
\hline North America & 42 \\
Central America, Caribbean and Orinoco basin & 15.5 \\
Amazon and Tocantins basin & 4.4 \\
Western Europe & 22 \\
\hline
\end{tabular}

population density, and Howarth (1998) found the same relationship for total $\mathrm{N}$ export from large temperate regions. Therefore, a tendency toward lower $\mathrm{N}$ to $\mathrm{P}$ ratios favoring $\mathrm{N}$ limitation could be attributed to increased agricultural development and urbanization independent of latitude.

Detailed analysis of the relative severity of $\mathrm{N}$ or $\mathrm{P}$ limitation in freshwaters requires $\mathrm{N}$ and $\mathrm{P}$ data on a wide range of tropical waters, although complete data are rarely available. Although not necessarily reflecting total $\mathrm{N}: \mathrm{P}$, more frequently available nitrate to orthophosphate molar ratios vary widely within the tropics (Table 3) with values for African rivers and streams below the molar Redfield ratio (16) and most values for South America above 16. The N:P ratios of fluvial fluxes of total dissolved $\mathrm{N}$ and $\mathbf{P}$ for the South and Central American waters in Table 4 are at or above the Redfield ratios. Waters of the Paraguay River (Pedrozo \& Bonetto 1989), the Paraná flood plain (Pedrozo et al. 1992), some Amazonian lakes (Forsburg 1984; Rai \& Hill 1980) have low N:P, while other Amazon lakes (Forsburg 1984) and some lakes in Brazil (Tundisi et al. 1991) and Venezuela (Gonzalez et al. 1991) have high N:P. It appears that there may be regional differences in the prevalence of $\mathrm{N}$ limitation among the freshwater ecosystems of the tropics.

There are few measurements of atmospheric deposition in the tropics spanning at least one year and including inorganic and organic fractions of N and P (e.g. Bootsma et al. 1996; Lesack \& Melack 1991; Lewis 1981); such data are sparse even for temperate regions. Hence, it is not possible to assemble a representative set of data on external loading via atmospheric deposition appropriate for testing hypotheses about the relative importance of $\mathrm{N}$ or $\mathrm{P}$ in tropical systems. The few data available show molar $\mathrm{N}$ to $\mathrm{P}$ ratios for dissolved inorganic N:P or total dissolved $\mathrm{N}$ and $\mathrm{P}$ that range from mid 20 s to almost 200. Dry deposition of $P$ is likely to lower these ratios, assuming that the particulate $P$ is available for algal uptake.

The extent to which the N:P ratio in external inputs determines the nutrient status of freshwater ecosystems depends partially on the relative magnitude 
Table 3. $\mathrm{N}$ to $\mathrm{P}$ ratios of rivers in various tropical regions expressed as molar $\mathrm{NO}_{3}$ to $\mathrm{PO}_{4}$ concentrations. Ratios of dissolved inorganic nutrients are used here because data in total river $\mathrm{N}$ and $\mathrm{P}$ budgets are frequently unavailable in the tropics.

\begin{tabular}{|c|c|}
\hline River/ Region & Ratio \\
\hline \multicolumn{2}{|l|}{ Africa } \\
\hline \multicolumn{2}{|l|}{ Uganda (Viner 1975) } \\
\hline Mt. Elgon rivers & 4 \\
\hline Karamoja rivers & 2 \\
\hline Central Uganda & 3 \\
\hline Semliki tributaries and Ituri forest streams & 5 \\
\hline Kigezi highlands rivers & 5 \\
\hline Ruwenzori mountains & 13 \\
\hline \multicolumn{2}{|l|}{ Kenya (Melack \& McIntrye 1991) } \\
\hline Aberdare and Bahati rivers & 8 \\
\hline Cherangani Hills rivers & 2 \\
\hline Zambezi (Hall et al. 1976) & 1 \\
\hline \multicolumn{2}{|l|}{ South America (Lewis et al. 1995) } \\
\hline \multicolumn{2}{|l|}{ Orinoco basin } \\
\hline Orinoco (lower) & 19 \\
\hline Apure & 7 \\
\hline Caura & 63 \\
\hline Caroni & 87 \\
\hline \multicolumn{2}{|l|}{ Amazon basin } \\
\hline Amazon (Obidos) & 14 \\
\hline Solimoes (Ica) & 16 \\
\hline Japura & 24 \\
\hline Jurua & 21 \\
\hline Negro & 30 \\
\hline Madeira & 10 \\
\hline Trombetas & 62 \\
\hline Xingu & 57 \\
\hline Tapajos & 100 \\
\hline
\end{tabular}


Table 4. $\mathrm{N}$ to $\mathrm{P}$ ratios expressed as fluxes of total dissolved $\mathrm{N}$ to total dissolved $\mathrm{P}$ or as fluxes of $\mathrm{NO}_{3}-\mathrm{N}$ plus dissolved organic $\mathrm{N}$ to $\mathrm{PO}_{4}-\mathrm{P}$ plus dissolved organic $\mathrm{P}$. These nutrient ratios are used here because data on total river $\mathrm{N}$ and $\mathrm{P}$ budgets are frequently unavailable in the tropics.

\begin{tabular}{lll}
\hline River/ Region & Ratio (molar) & Reference \\
\hline Paraguay & 51 & Hamilton et al. (1997) \\
Amazon basin & & \\
$\quad$ Ica & 20 & JR Richey (unpubl.) \\
Jutai & 20 & JR Richey (unpubl.) \\
Jurua & 15 & JR Richey (unpubl.) \\
Japura & 18 & JR Richey (unpubl.) \\
Purus & 18 & JR Richey (unpubl.) \\
Negro & 15 & JR Richey (unpubl.) \\
Madeira & 15 & JR Richey (unpubl.) \\
Mota Brook & 194 & Lesack (1993) \\
Mota Brook & 46 & Williams \& Melack (1997) \\
Orinoco (lower) & 31 & Lewis \& Saunders (1989) \\
Apure & 15 & Saunders \& Lewis (1988) \\
Costa Rica & & \\
$\quad$ Northwestern streams & 42 & Newbold et al. (1995) \\
\hline
\end{tabular}

of external inputs, internal recycling and vertical mixing and losses, and their respective N:P ratios. Such information is available for only a few tropical lakes. Two contrasting examples (Lake Malawi and Lake Calado, Brazil) help demonstrate the balance between external and internal nutrient supply.

Lake Malawi, one of the African Great Lakes, has a hydraulic flushing time of 750 years and is permanently anoxic below about $200 \mathrm{~m}$ (Hecky et al. 1996). The annual fluvial and atmospheric inputs to the mixed layer have $\mathrm{N}$ to $\mathrm{P}$ molar ratios of 23 and 43 , respectively. About $80 \%$ of the $\mathrm{N}$ input is supplied by nitrogen fixation. Vertical mixing provides about $88 \%$ of the $\mathrm{P}$, but essentially no $\mathrm{N}$ to the mixed layer. Fluvial outflow is small and has an N:P ratio of 30 ; loss to burial in sediments is unmeasured; an N:P ratio for annual burial of about 30 is estimated for neighboring Lake Tanganyika. Although the N:P ratios in fluvial and atmospheric inputs would indicate a P-limited mixed layer, the dominance of vertical mixing as the route of supply of phosphorus $(\mathrm{N}: \mathrm{P} \approx 0)$, requires a large $\mathrm{N}$ supply by nitrogen fixation to avoid severe $\mathrm{N}$ limitation. The presence of a continuous oxic-anoxic interface in the water column acts as a sink for dissolved inorganic $\mathrm{N}$ because of denitrification, but has little influence on the upward flux of P (Hecky et al. 1996). 
The common occurrence of anoxic hypolimnia in tropical lakes may be an important factor leading to low $\mathrm{N}$ to $\mathrm{P}$ ratios associated with vertical mixing, which is often a major source of nutrients to the euphotic zone, and which may stimulate $\mathrm{N}$ fixation or lead to $\mathrm{N}$ limitation.

Lake Calado, a shallow floodplain lake bordering the Solimóes River in the central Amazon basin, ranges in area from about 2 to $8 \mathrm{~km}^{2}$ as a function of annual variation in river stage (Lesack \& Melack 1995). Estimates of inputs, recycling and exports of $\mathrm{N}$ and $\mathrm{P}$ for Lake Calado have been published (Doyle \& Fisher 1994; Fisher et al. 1991; Melack \& Fisher 1990). Inputs to Lake Calado from rain, upland runoff, groundwater seepage, adjacent lakes, and riverine inflows had an aggregate molar N:P ratio of 32 . Internal recycling by bacteria and zooplankton within the water column and by regeneration from sediments had molar N:P ratios of 4 and 7, respectively. Because the magnitude of internal recycling exceeded external supply, the overall $\mathrm{N}: \mathrm{P}$ ratio for supply was 5 . Losses via burial as sediments and outflow to the river (but not including gaseous losses of $\mathrm{N}$ ) had an N:P ratio of 20 . Nitrogen fixation provided about $8 \%$ of the total annual $\mathrm{N}$ inputs. While these annual $\mathrm{N}: \mathrm{P}$ supply ratios are indicative of $\mathrm{N}$ limitation, experimental enrichments, and physiological assays detected weekly and seasonal differences in nutrient limitation due in part to the variable incursion of river water (Setaro $\&$ Melack 1984). Hence, short-term variations in the relative magnitude of various routes of nutrient supply with different $\mathrm{N}: \mathrm{P}$ ratios can change the importance of $\mathrm{N}$ or $\mathrm{P}$ as limiting nutrients. The Lake Malawi and Calado data suggest that increases in $\mathrm{N}$ loading of freshwaters will have a proportionately greater impact on tropical lakes than temperate ones.

Some information on the relative probabilities of $\mathrm{N}$ - or P-limitation in tropical freshwaters can be gained by examining average total $\mathrm{N}$ and $\mathrm{P}$ concentrations in tropical waters. Although such data are relatively rare, a joint PAHO/WHO program created to predict responses of unimpacted tropical lakes to cultural eutrophication assembled $\mathrm{N}$ and $\mathrm{P}$ data on 24 warm, tropical lakes in Argentina, Brazil, Colombia, Ecuador, Mexico, Puerto Rico, and Venezuela (Salas \& Martino 1991). When these data are compared with similar data collected in temperate lakes (Downing \& McCauley 1992), it appears that they follow quantitatively different trends (Figure 7). Tropical lakes in the Americas are generally very rich in nutrients and therefore have $\mathrm{N}: \mathrm{P}$ ratios that cluster closer to $\mathrm{N}: \mathrm{P}=16$, but are not dissimilar from rich temperate lakes. A greater proportion of tropical lakes (29\%) than temperate (3\%) have N:P $<16$ (Downing \& McCauley 1992). This suggests that denitrification in tropical ponds, lakes, and streams must be very rapid because water leaving tropical forests has high N:P ratios (Figure 7; Bruijnzeel 1991; Williams \& Melack 1997). 


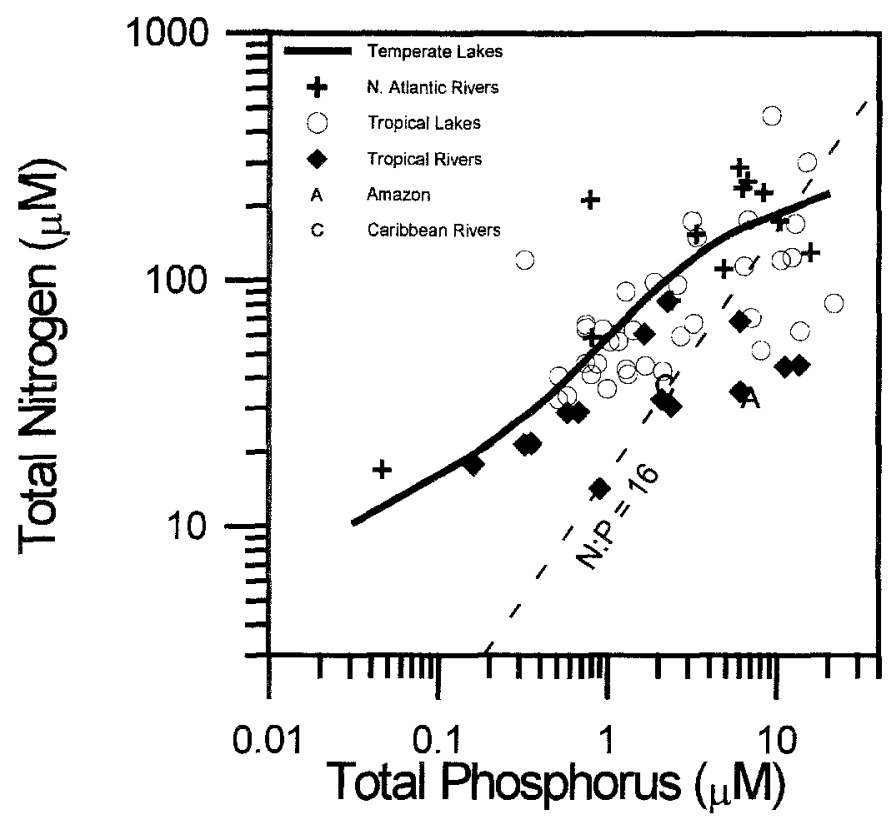

Figure 7. Relationship between the nitrogen and phosphorus concentration in temperate and tropical freshwater ecosystems. The solid line shows data on temperate lake nutrients shows the LOWESS fitted general trend derived from several hundred sets of measurements on average temperature lake nutrients (Downing \& McCauley 1992). Tropical lake data are from Salas \& Martino (1991). Concentrations of $\mathrm{N}$ and $\mathrm{P}$ in tributaries to the North Atlantic, including Caribbean rivers ("C") and the Amazon \& Tocantins Basins ("A") are flow weighted averages from Howarth et al. (1996). Other tropical river data are principally pristine South American rivers and streams (Lesack 1993; Lewis et al. 1995) and data from the Gambia River in Africa (Lesack 1984).

Because low ambient N:P ratios are indicative of $\mathrm{N}$ limitation (Downing \& McCauley 1992; Elser et al. 1990), it is likely that $\mathrm{N}$ is more frequently limiting to freshwater production in tropical lakes despite the high N:P in nutrient supplies from undisturbed forested catchments. Likewise, undisturbed tropical streams and rivers have lower concentrations of $\mathrm{N}$ for a given concentration of $\mathrm{P}$ than do tropical lakes or temperate lakes and rivers (Figure 7). This suggests that $\mathrm{N}$ is lost from aquatic systems more rapidly in the tropics than the temperate zone (e.g. through denitrification), and phosphorus erosion from tropical landscapes and phosphorus mobilization in aquatic environments are more rapid. Whatever the pathway, it is clear that nitrogen is frequently limiting to production in tropical freshwaters (Saijo et al. 1997; Furch \& Junk 1993; Forsburg 1984; Henry et al. 1984).

In summary, it is difficult to predict with certainty how tropical freshwater systems will respond to altered nutrient supplies and ratios because of the 
relative paucity of data. It is especially important to make measurements of organic $\mathrm{N}$ and $\mathrm{P}$ fractions in atmospheric deposition, and to conduct studies that include recycling, vertical mixing and losses as well as inputs. Based on the available data on N:P ratios in fluvial inputs and lakes, however, it seems likely that $\mathrm{N}$ will be more frequently limiting to production in tropical freshwater systems than in the temperate zone. The common occurrence of an oxic-anoxic interface in the water column of tropical lakes may increase the likelihood of low N:P ratios, stimulating nitrogen fixation or leading to intensified nitrogen limitation.

\section{Ecological effects of $\mathbf{N} / \mathbf{P}$ alterations on tropical aquatic communities}

The evidence presented above suggests that the probable sequence of disturbance will lead to $\mathrm{N}$ and $\mathrm{P}$ enrichment and progressive declines in the $\mathrm{N}: \mathrm{P}$ of nutrient supplies. The coupling of the major biogeochemical cycles is critically important for evaluating the ecological impact of changes in them (Elser in review; Howarth 1988; Howarth et al. 1996; Sterner et al. 1997; Wollast et al. 1993). Resource ratio competition theory (Tilman 1982) can help develop broad predictions about the impact of increased $\mathrm{N}$ loading and stoichiometric shifts in supply with tropical disturbance.

To illustrate stoichiometric changes in tropical aquatic ecosystems, "Zero net growth isoclines" (combinations of $\mathrm{N}$ and $\mathrm{P}$ supply rates where population growth rate exactly balances losses such that net growth is zero) for nine hypothetical algal species are shown in Figure 8. The competitive abilities of various algal taxa usually follow a normal distribution (Andersen 1997), and thus in most situations the greatest diversity of algal taxa will be supported at intermediate N:P supply ratios. The species at the upper left of the figure are good competitors for $\mathrm{P}$, but relatively poor competitors for $\mathrm{N}$. The species to the right are good competitors for $\mathrm{N}$ but poor competitors for $\mathrm{P}$. The "ultimate" good competitor for $\mathrm{N}$ is an $\mathrm{N}$-fixing species (e.g. species 8 and 9) that might be abundant under the relatively $\mathrm{N}$-limited conditions in the tropics. If much $\mathrm{N}$, but little $\mathrm{P}$, is supplied, good P-competitors will dominate. If much $\mathrm{P}$, but little $\mathrm{N}$, is supplied, as will probably be the case under increased disturbance in the tropics, good $\mathrm{N}$-competitors (e.g., species 7 and 8) will reduce $\mathrm{N}$ levels below those at which other taxa can survive.

Resource ratio theory predicts different community responses of temperate and tropical systems to increased loading. Temperate lakes are usually P-limited with naturally high N:P loading ratios (Region A, Figure 8), so increased $\mathrm{N}$ loading accompanied by a proportional increase in $\mathrm{P}$ inputs (arrow I, Figure 8) has had significant yet modest effecis on community structure. In N-limited (low N:P) waters (scenario B, Figure 8) or those 


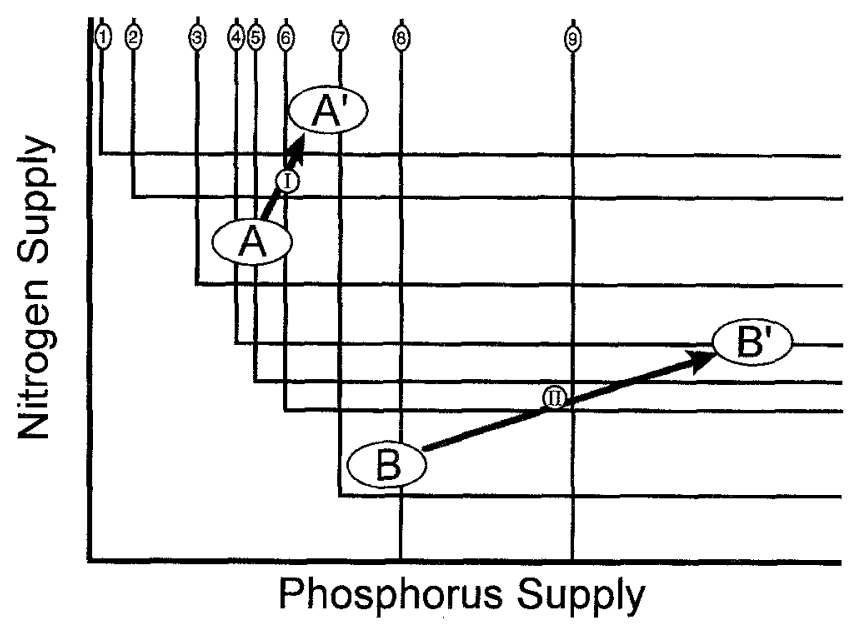

Figure 8. A generalized set of "zero net growth isoclines" ("ZNGI's) for 9 hypothetical algal species in which there is a trade-off in competitive abilities for $\mathrm{N}$ and $\mathrm{P}$. For a given species, the ZNGI indicates the set of minimal supply rates for $\mathrm{N}$ and $\mathrm{P}$ at which net growth rate falls to zero for a given total loss rate. Species 1 and 2 are particularly good competitors for $\mathrm{P}$ but have elevated requirements for $\mathrm{N}$ supply. Conversely, species 8 and 9 represent $\mathrm{N}$-fixing taxa with high minimal $\mathrm{P}$ requirements. The trajectories indicated by arrows I and II show scenarios of algal community response to perturbations of $\mathrm{N}$ supply under contrasting ecological conditions, representing changes observed in temperate freshwaters (I) and predicted for tropical freshwaters (II).

where $\mathrm{N}$ and $\mathrm{P}$ are nearly co-limiting, such as those that are common among oligotrophic lakes in the western U.S. (Horne \& Galat 1985; Morris \& Lewis 1988) and among many lakes in the tropics (Figure 7.; Lewis 1996; Setaro \& Melack 1984; Wurtsbaugh et al. 1985), increased N loading that is coupled to increased P loading (N:P load decreasing; arrow II, Figure 8) would have relatively large effects on algal community structure, simplifying the community to those very few species adapted to extremely low $\mathrm{N}: \mathrm{P}$ supply ratios. Given the predominantly low N:P of runoff under anthropogenic influence (Table 1), increasing disturbance in the tropics will lead to disproportionate enrichment of $\mathbf{P}$ relative to $\mathrm{N}$, resulting in decreasing $\mathrm{N}: \mathrm{P}$ ratios (Figure 5). Nitrogen limitation is therefore likely to become progressively more severe as disturbance and development proceed, leading to an even greater decrease in algal diversity than that seen in culturally eutrophied temperate freshwaters.

Discrepancies between the highly variable elemental composition of phytoplankton and the rigidly regulated composition of consumers (Andersen \& Hessen 1991; Elser et al. 1996; Elser et al. 1998; Sterner et al. 1993; Sterner \& Hessen 1994) will likely destabilize tropical freshwaters under increasing landscape disturbance. The growth and reproduction of consumers can be 
limited by the nutrient content of its food (Sterner 1994), creating trophic bottlenecks (Elser et al. 1998; Sterner et al. 1997) that limit the rates and ratios at which consumers cycle nutrients (Elser et al. 1988; Olsen et al. 1986; Sterner 1990; Urabe 1995). Models (i.e., Andersen 1993, 1997) predict that if $\mathrm{N}$ loading is coupled to increased $\mathrm{P}$ loading as expected in tropical freshwaters, trophic destabilization will result from tropical eutrophication. Because major biomolecules (e.g. proteins vs. nucleic acids) differ little in nitrogen content (Elser et al. 1996) but greatly in phosphorus content, most consumer taxa should have similar nutritional requirements for $\mathrm{N}$ but broadly variable $\mathrm{P}$ requirements. Worsening food quality resulting from $\mathrm{N}$ limitation may eventually drive food $\mathrm{C}: \mathrm{N}$ ratios to a critically high level where the majority of grazer taxa suffer nutritional imbalances. Under increasing algal $\mathrm{N}$ limitation such as that expected in the tropics, impacts on food webs may potentially disruptive to ecosystem function. Because tropical freshwater systems are currently frequently $\mathrm{N}$-limited, it is likely that ecosystem-level impacts of land-use change will be more severe than those seen in the temperate zone.

\section{Altered nutrient export to estuaries}

Evidence has been presented above that tropical freshwaters supply more nutrient flux than undisturbed rivers of the temperate zone (Figures 1 and 7), that the nitrogen contained in this flux is roughly $35 \%$ dissolved inorganic $\mathrm{N}$ (Lewis et al., this volume), and that tropical headwater streams have lower $\mathrm{N}: \mathrm{P}$ ratios than their counterparts in the temperate zone (Table 2, Figure 7). Future land-use change in the tropics will be likely to greatly alter $\mathrm{N}$ flux to tropical estuaries (Figure 3); this $\mathrm{N}$-flux will be increasingly dominated by dissolved inorganic forms of N (Figure 4); and nutrients may be increasingly supplied at $\mathrm{N}: \mathrm{P}$ below the Redfield ratio (Table 1, Figure 3). These observations combine to suggest that tropical estuaries of the future will experience nutrient supplies that are much higher than current concentrations, and that these supplies will have decreasing N:P ratios leading to eutrophication and stronger nitrogen limitation. Increased nutrient loading to estuaries will probably accentuate nitrogen limitation.

\section{Shifts in $\mathbf{N}$ and $\mathbf{P}$ limitation in tropical coastal ecosystems}

The often high levels of nutrient loading and the low $\mathrm{N}: \mathrm{P}$ in inputs to tropical coastal systems from rivers suggest that marine waters near river outflows must frequently be $\mathrm{N}$-limited. Suspended silt loads carried by tropical rivers, however, block light and probably also result in light-limited production of 
benthic and planktonic systems. Nutrient inputs and factors limiting primary productivity in tropical coastal waters will therefore vary according to a continuum of geomorphological settings that differ in nutrient concentrations and light availability from deltaic, estuaries and lagoons, to reef and planktonic environments. The amounts of solar, chemical and mechanical energy together with regional geomorphology must establish the template from which site-specific patterns of primary productivity will develop. Together, these geophysical factors control the distribution of resources (such as light and nutrients) as well as establishing levels of stress (temperature and salinity) that largely determine the net productivity of aquatic ecosystems. These characteristics will strongly influence the responses of marine ecosystems to increased nutrient flux.

Most classification systems of marine ecology have accounted for the importance of the physical nature of coastal environments to the types of communities that develop (Hedgpeth 1957; Odum et al. 1972). Geomorphic and geophysical characteristics of coastal zones, along with regional climate, have been recognized as important constraints on the structure of tropical coastal ecosystems (Yanez-Arancibia 1987) including plant formations, such as mangroves (Blasco 1984; Thom 1982; Twilley 1995). In addition, the relative contributions of primary producers to total energy flow of coastal systems can be associated with regional patterns of geomorphology and hydrography, particularly river inflow (Mann 1975; Welsh et al. 1982). For example, the ratio of wetland area to the area of coastal waters has been suggested as important to the contribution of coastal wetlands to the secondary productivity of estuaries (Mann 1975; Rojas Galaviz et al. 1992; Welsh et al. 1982). Landform characteristics of a coastal region and environmental processes such as river discharge, tides, wind and waves control the types of primary producers, their relative spatial distribution and abundance, as well as rates of primary productivity. Classes of environmental settings based on energy spectrum and source of sediments have been used to generalize patterns of coastal geomorphology including reefs, lagoons, estuaries (drowned river valleys), and deltas (Figure 9). The response of coastal ecosystems to increases in $\mathrm{N}$ will likely be associated with these different patterns of geophysical forces and geomorphological processes.

The susceptibility of tropical coastal systems to eutrophication will vary with the geomorphological setting (Figure 9). Conceptual templates of coastal systems that integrate geomorphology and water residence time (geophysical processes) with biogeochemical processes allow understanding of the ways in which coastal ecosystems will respond to nutrient inputs. Variation of available light and nutrients are two key factors limiting primary productivity among the geomorphological types. Reefs are among the marine environ- 


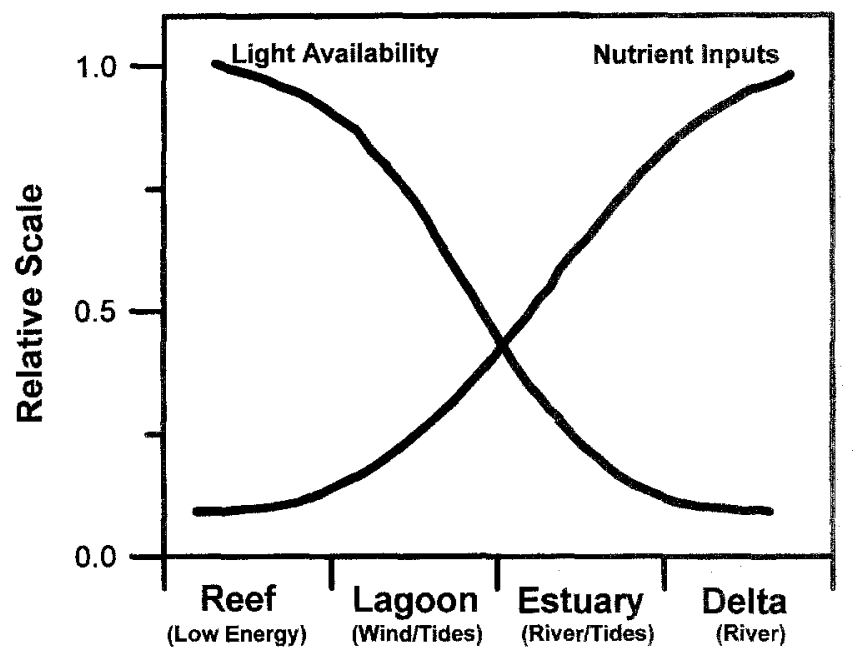

Geomorphic Setting

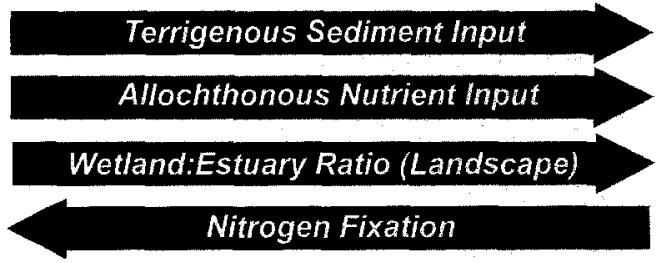

Figure 9. Conceptual framework of variations in the distribution of available light and nutrients inputs among different types of estuaries based on geomorphology from carbonate reefs to river-dominated deltas. Hypotheses concerning the relative amounts of sediment and nutrient inputs, including nitrogen fixation, and wetland:estuary ratio are indicated with increasing amounts of each occurring in the direction of the arrows.

ments most remote from terrestrial disturbance impacts on the global $\mathrm{N}$-cycle. Reef environments have in situ production of sediments that are low in nutrients, have very clear waters and low wave energies that support productive seagrass and coral communities, yet phytoplankton production is low. On the other extreme, deltaic environments have very limited light, but are rich in nutrients, where high productivity is associated with intertidal communities that receive fertile sediments. There is a transition in the relative contribution of planktonic, benthic, and intertidal primary producers to net ecosystem productivity along this continuum of geomorphological settings related to the distribution of light and nutrient resources. The trajectory that each type of primary producer will follow as nutrient levels increase will determine the pattern of eutrophication in each coastal setting. In the case of reefs, benthic and planktonic producers will be sensitive to nutrient loading compared to 
deltaic systems where the response to nutrient loading will be less dramatic and more spatially removed to high light environments downstream of river plumes (see below). The issue of nutrient limitation, then, is a key issue in geomorphological settings that are less light limited, compared to more fertile environments where light limitation may currently be more critical than nutrients. Therefore, whereas responses of deltaic systems to increased nutrient loading may be minor, the extent of the high production zone surrounding the river delta will be greatly expanded, altering large-scale patterns in natural marine production gradients.

The paradigm that $\mathrm{N}$ is the key limiting nutrient to coastal marine ecosystems has largely been restricted to temperate environments (Howarth 1988). Stoichiometric data on nutrient export from freshwater ecosystems (e.g. Tables 2 and 4; Figure 7) as well as direct experimental evidence (Teixeira \& Tundisi 1981; Downing et al. 1999) suggest that $\mathrm{N}$ limitation may also be general in tropical coastal ecosystems. There is now increasing evidence, however, that $\mathrm{P}$ may be a key nutrient limiting the primary productivity of some tropical marine ecosystems, particularly in carbonate dominated sediment environments (Corredor et al., this volume; reef settings in Figure 9), or in the open tropical ocean (Downing 1997). As is the case in temperate coastal systems, it is important that the role of nutrient limitation be described relative to specific types of primary producers. In the tropics, it is clear that $\mathrm{P}$ rather than $\mathrm{N}$ can limit primary productivity of mangrove (Feller 1995) and seagrass (Short et al. 1985) communities. In addition, tropical planktonic and macroalgae communities can be limited by $P$ availability in at least some oligotrophic reef environments (Fourqurean et al. 1993). The relative importance of $\mathrm{P}$ biogeochemistry to carbon dynamics and new production of tropical marine ecosystems has been proposed from stoichiometric studies of coastal systems in Hawaii (Smith 1984). These studies provide a systemslevel understanding of how productivity will respond to eutrophication of shallow reef environments (D'Elia \& Wiebe 1990). As in tropical freshwaters, the impact of $\mathrm{N}$ loading on marine environments strongly depends upon shifts in the stoichiometry of the nutrient supply.

There is little information to indicate how the diverse types of coastal environments in Figure 9 will respond to $\mathrm{N}$ enrichment. It is clear that tropical marine systems with calcareous sediments can be P-limited when nutrient fluxes are low. These systems are sensitive to eutrophication, which could cause a shift to $\mathrm{N}$ control of production if the $\mathrm{P}$ immobilization capacity of calcareous environments is compromised, or there is an eventual shift to light limitation. If $\mathrm{N}$ loading increases to $\mathrm{P}$-limited systems without alterations in the $\mathrm{P}$ load, they will become more severely P-limited, and algal C:P will increase, eventually influencing seston quality. If changes in $\mathrm{P}$ rise more 
rapidly than $\mathrm{N}$ loading, as expected (see above and Figure 5), it is likely that $\mathrm{P}$ limitation will be replaced by $\mathrm{N}$ limitation, even in calcareous tropical marine ecosystems. There is a critical need for information on the biogeochemistry of $\mathrm{C}, \mathrm{N}$, and $\mathrm{P}$ in coastal ecosystems of the tropics, particularly in reaction to shifts in N:P ratios as a result of internal nutrient regeneration processes (see similar needs in lakes, above). The conceptual framework proposed here suggests that these patterns of biogeochemistry and susceptibility to $\mathrm{N}$ loading will vary depending on the geophysical and geomorphological characteristics of the coastal landscape.

\section{Evidence of the effects of anthropogenic nutrients on coastal tropical ecosystems}

Tropical coastal planktonic communities are most frequently nitrogen or light limited, and the impact of natural river exported nutrients (low in

$\mathrm{N}: \mathrm{P})$ will eventually extend far beyond the river mouth. The seasonal influence of tropical rivers such as the Orinoco and Amazon has been shown to extend throughout the Eastern Caribbean Basin (Yoshioka et al. 1985). Recent evidence suggests that tropical river-borne nutrients are carried great distances because they are complexed with dissolved organic matter, and these complexes only slowly degrade by UV and bacterial activity (Bonilla et al. 1993; Carlsson et al. 1993; Moran \& Hodson 1994). Although there is some controversy concerning the relative roles of $\mathrm{N}$ and $\mathrm{P}$ in limiting marine plankton production (Downing 1997; Downing et al. 1999; Howarth 1988; Smith 1984; Vitousek \& Howarth 1991), the predominance of nitrogen fixing cyanobacteria in nutrient depleted oceanic waters (Carpenter 1983; Margalef 1971) and the preferential uptake of nitrogen by phytoplankton when nutrient limitation is relieved through upwelling (Corredor 1979) suggest that $\mathrm{N}$ is the most frequently limiting nutrient in the Caribbean and tropical Atlantic planktonic systems. Further evidence of current $\mathrm{N}$ limitation in the tropics is supplied by the high rates of $\mathrm{N}$ limitation seen in coastal waters (Diaz et al. 1990), and the strong responses of cyanobacteria to inorganic $N$ enrichment (Corredor et al. 1994).

Human activities in the tropics have already begun to cause large imbalances in the marine coastal nitrogen cycle. Anthropogenic nutrient inputs due to increased fertilizer use, land development, soil erosion and sewage discharges have brought about rapid changes in algal communities. Filamentous cyanobacteria and chlorophytes have begun to dominate the phytobenthos in many places. The filamentous cyanophyte Microcoleus lyngbyaceus has now formed monospecific mats over the shallow benthos around Puerto Rico, in response to anthropogenic eutrophication (Corredor et al. 1994; Diaz et 
al. 1990). These mats have displaced the normal benthic community and depleted dissolved oxygen. Fleshy green algae can rapidly overgrow corals in response to anthropogenic nutrient inputs, as shown for Hawaiian reefs (Smith 1984). While excessive proliferation of these species has not been documented in marine waters of the American tropics, other algae (e.g. the calcareous green alga Halimeda) have shown rapid growth (Corredor, unpublished). Increased inputs of nutrients to tropical systems are already leading to large changes in these communities.

Although coastal denitrification significantly buffers the impact of increased nitrogen loading in the temperate zone (Seitzinger 1988), nitrification in tropical marine systems may be more severely constrained by relatively low oxygen concentrations of warm waters, especially those with active microbial floras typical of polluted coastal zones. Denitrification rates in mangrove ecosystems are controversial (Corredor \& Morell 1994; Rivera-Monroy \& Twilley 1996). Nitrogen delivered to the tropical marine ecosystem, therefore, will probably persist longer and thereby have a greater impact than in temperate marine ecosystems.

\section{Overview of hypotheses and needs for future research}

The preceding overview and comparisons suggest that differences in background nutrient environments between tropical and temperate systems will lead to greater impacts of human population growth and agricultural and industrial development on tropical aquatic ecosystems. Tropical freshwater systems are more frequently $\mathrm{N}$-limited than temperate zones, while tropical marine systems may be more frequently P-limited than comparable areas in temperate zones. This means that disturbances to pristine tropical lands will likely lead to greatly increased primary production in freshwaters, an expansion of the high production, $\mathrm{N}$ - and light-limited zones around river deltas, and a switch from $\mathrm{P}$ - to $\mathrm{N}$-limitation with large changes in the community composition of fragile mangrove and reef ecosystems.

This review was assembled using as much empirical data on tropical nutrient cycles as we could find, but many facets of this issue will only be resolved by filling in critical gaps in existing knowledge. Although it is clear from existing evidence that $\mathrm{N}$ loss rates are higher from undisturbed tropical ecosystems than their temperate counterparts, it is unclear why these $\mathrm{N}$-export rates are so high or how these $\mathrm{N}$-loss mechanisms will react to altered landuse. Under pristine conditions, even modeled atmospheric N-deposition is calculated to be higher in the tropics than temperate zones, but we currently have little solid data on how atmospheric $\mathrm{N}$-deposition might react to disturbance or how expected increases in $\mathrm{NO}_{x}: \mathrm{NH}_{y}$ will impact denitrification or 
river transport of atmospheric N. Research on the mechanisms of nutrient transport and atmospheric deposition in the tropics is vital to understanding the probable impacts of land-use disturbance.

We have used a conceptual model built from tropical and temperate geochemical experience to project a trajectory of change in aquatic $\mathrm{N}$ concentrations and N:P stoichiometry as land-use is altered in the tropics. Although we think it likely that tropical ecosystems will follow this trajectory, the $\mathrm{N}$ flux and $\mathrm{N}: \mathrm{P}$ database is quite thin and needs field testing. Critical questions concern shielding tropical aquatic systems from excess nutrient, sediment, and nutrient loads through the use of riparian buffers and other management practices throughout the phases of deforestation, burning and agricultural development. The proper management of reservoirs and water-management projects offer a potentially important means of controlling nutrient loads, thus research is needed to examine characteristics of the growing number of tropical impoundments that might lead to more effective nutrient retention and lowered downstream impacts on freshwater and marine ecosystems. Research is needed to evaluate ways to buffer the major changes in nitrogen export that can be expected from large-scale disturbance and development of tropical lands.

We strongly emphasize the need for research that recognizes the impact of altered nutrient stoichiometry on tropical aquatic ecosystem function. Although it appears that $\mathrm{N}$ limitation of freshwater systems is more prevalent in the tropics than temperate zones, research on the prevalence and mechanism of $\mathrm{N}$ limitation in tropical ecosystems is needed to understand how freshwater production and community structure will be altered by land-use changes. The database on $\mathrm{N}$ and $\mathrm{P}$ cycling in tropical freshwater lakes, ponds and rivers is particularly incomplete, and we need a fuller understanding of the mechanisms coupling or uncoupling the fluxes of $\mathrm{N}, \mathrm{P}$ and other major nutrients from disturbed tropical ecosystems. Relationships between tropical aquatic community structure and nutrient stoichiometry must be worked out, especially to predict how noxious algal species are impacted by altered stoichiometry and nutrient supply. The potential destabilization of trophic interactions by altered nutrient ratios suggests that research is needed to determine the optimal $\mathrm{N}$ and $\mathrm{P}$ needs of key components of tropical aquatic food webs.

The tropics contain a large variety of marine ecosystems that vary in nutrient limitation from $\mathrm{P}$-limited mangroves and reefs to $\mathrm{N}$-limited coastal zones to deltaic receiving waters limited by light penetration through turbid waters. Prediction of the impact of altered nutrient flux requires a better understanding of how light, $\mathrm{N}$ and $\mathrm{P}$ limitation combine to determine rates of production and community structure in tropical marine littoral, benthic, and planktonic 
ecosystems. Disruption of land-use patterns will clearly alter nutrient availability to the marine environment, but it is important to determine how light and nutrients might interact to alter large-scale patterns in marine production. Impacts of changing ratios of nutrient supply on calcareous tropical marine communities (e.g. reefs) are particularly poorly understood, thus prediction of tropical marine impacts requires knowledge of the mechanisms through which nutrient stoichiometry influences marine nutrient limitation.

Land-use changes have greatly altered temperate nutrient cycles, and similar land-use changes are occurring at a rapid rate in the tropics. The current base of biogeochemical data suggests that alterations in the $\mathrm{N}$-cycle will have greater impacts on tropical ecosystems than those already seen in temperate zones. As tropical development proceeds, the research outlined above could go far toward protecting tropical aquatic ecosystems from the problems experienced in the temperate zone as a result of anthropogenic enhancement of nutrient flux.

\section{References}

Andersen T \& Hessen DO (1991) Carbon, nitrogen, and phosphorus content of freshwater zooplankton. Limnol. Oceanogr. 36: 807-814

Andersen T (1993) Grazers as Sources and Sinks for Nutrients. PhD Dissertation, University of Oslo, Norway

Andersen T (1997) Pelagic Nutrient Cycles: Herbivores as Sources and Sinks. SpringerVerlag, Berlin, Germany

Arcifa MS, Carvalho MAJ, Gianesella-Galvao SMF, Shimizu GY, Froehlich CG \& Castro RMC (1981a) Limnology of ten reservoirs in Southern Brazil. Verh. Internat. Verein. Limnol. 21: 1048-1053

Arcifa MS, Froehlich CG \& Gianesell-Galvao SMF (1981b) Circulation patterns and their influence on physico-chemical and biological conditions in eight reservoirs in Southern Brazil. Verh. Internat. Verein. Limnol. 21: 1054-1059

Arheimer B \& Witgren HB (1994) Modeling the effects of wetlands on regional nitrogen transport. Ambio 23: 378-286

Asner GP, Seastedt TR \& Townsend AR (1997) The decoupling of terrestrial carbon and nitrogen cycles. BioScience 47: 226-234

Bailey C, Jentoft S \& Sinclair P (1996) Aquacultural Development: Social Dimensions of an Emerging Industry. Westview Press, Boulder, CO, U.S.A.

Beaulac MN \& Reckhow KH (1982) An examination of land-use-nutrient export relationships. Water Resources Bulletin 18: 1013-1024

Behrens CA, Baksh MG \& Mothes M (1994) A regional analysis of Barí land use intensification and its impact on landscape heterogeneity. Human Ecology 22: 279--316

Billen G, Lancelot C \& Meybeck M (1991) N, P, and Si retention along the aquatic continuum from land to ocean. In: Mantoura RFC, Martin JM \& Wollast R (Eds) Ocean Margin Processes in Global Change (pp 19-44). Wiley \& Sons, Chichester 
Blasco F (1984) Climatic factors and the biology of mangrove plants. In: Snedaker SC \& Snedaker JG (Eds) The Mangrove Ecosystem: Research Methods (pp 18-35). UNESCO, Paris, France

Bonetto C, De Cabo L, Gabillone N, Vinocur A, Donadelli J \& Unrein F (1994) Nutrient dynamics in the deltaic floodplain of the Lower Paraná River. Arch. Hydrobiol. 131: $277-$ 295

Bonilla J, Senior W, Bugden J, Zafiriou O \& Jones R (1993) Seasonal distribution of nutrients and primary productivity on the eastern continental shelf of Venezuela as influenced by the Orinoco River. J. Geophys. Res. 98: 2245-2257

Bootsma HA, Bootsma MJ \& Hecky RE (1996) The chemical composition of precipitation and its significance to the nutrient budget of Lake Malawi. In: Johnson TC \& Odada EO (Eds) Limnology, Climatology and Paleoclimatology of the East African Lakes (pp 251-265). Gordon \& Breach, Amsterdam, The Netherlands

Brandes M, Chowdhry NA \& Cheng WW (1974) Experimental study on removal of pollutants from domestic sewage by underdrained soil filters. In: American Society of Agricultural Engineers, Proceedings of the National Home Sewage Disposal Symposium (pp 29-36)

Brodizio ES, Moran EF, Mausel P \& Wu Y (1994) Land use change in the Amazon estuary: patterns of Caboclo settlement and landscape management. Human Ecology 22: 249-278

Bruijnzeel LA (1990) Hydrology of Moist Tropical Forests and Effects of Conversion: A State of Knowledge Review. Humid Tropics Program, UNESCO Int. Hydrological Program

Bruijnzeel LA (1991) Nutrient input-output budgets and tropical forest ecosystems: A review. J. Tropical Ecology 7: 1-24

Bruijnzeel LA (1996) Predicting the hydrological impacts of land cover transformation in the humid tropics: the need for integrated research. In: Gash JHC, Nobre CA, Roberts JM \& Victoria RL (Eds) Amazonian Deforestation and Climate (pp 15-55). John Wiley \& Sons, New York, NY, U.S.A.

Carlsson P, Segatto AZ \& Granéli E (1993) Nitrogen bound to humic matter of terrestrial origin - a nitrogen pool for coastal phytoplankton? Marine Ecology Progress Series 97: $105-116$

Carpenter EJ (1983) Nitrogen fixation by marine Oscillatoria (Trichodesmium) in the world's ocean. In: Carpenter EJ \& Capone DG (Eds) Nitrogen in the Marine Environment. Academic Press, New York, NY, U.S.A.

Chowdhury MK \& Rosario EL (1993) Nitrogen utilization efficiency as affected by component populations in maize-mungbean intercropping. Trop. Agric. 70: 199-204

Cole JJ, Peirls BL, Caraco NF \& Pace ML (1993) Nitrogen loading of rivers as a human driven process. In: McDonnell MJ \& Pickett STA (Eds) Humans as Components of Ecosystems: The Ecology of Subtle Human Effects and Populated Areas (pp 141-157). Springer-Verlag, New York, NY, U.S.A.

Cooke GD, Welch EB, Peterson SA \& Newroth PR (1993) Restoration and Management of Lakes and Reservoirs, 2nd Edn. Lewis Publishers, Boca Raton, FL, U.S.A.

Corredor JE (1979) Phytoplankton response to low-level nutrient enrichment through upwelling in the Colombia Caribbean Basin. Deep-Sea Research 26A: 731-741

Corredor JE \& Morell JM (1989) Nitrate depuration of secondary sewage effluents in mangrove sediments. Estuaries 17: 295-300

Corredor JE, Morell JM \& Díaz MR (1994) Environmental degradation, nitrogen dynamics and proliferation of the filamentous cyanophyte Microcoleus lyngbyaceus in nearshore Caribbean waters. In: Amato E (Ed.) Mediterraneo e Caraibe due Mari in Pericolo? Sversamenti Accidentali di Idrocarburi ed Emegenze Causate Dalle Alghe. ICRAM/IFREMER. Atti Convegno Internatzionale, Genova 
Day JW Jr \& Kemp P (1985) Long-term impacts of agricultural runoff in a Louisiana swamp forest. In: Godfrey PJ, Haynor ER, Pelczarski S \& Benforado J (Eds) Ecological Considerations in Wetlands Treatment of Municipal Wastewaters (pp 317-326). Van Nostrand, New York, U.S.A.

Deare FM, Ahmad N \& Ferguson TU (1995) Downward movement of nitrate and ammonium nitrogen in a flatland ultisol. Fertilizer Research 42: 175-184

D'Elia CF \& Wiebe WJ (1990) Biogeochemical nutrient cycles in coral-reef ecosystems. In: Dubinsky Z (Ed.) Ecosystems of the world 25, Coral reefs (pp 49-74). Elsevier, Amsterdam, The Netherlands

Díaz MR, Corredor JE \& Morell JM (1990) Inorganic nitrogen uptake by Microcoleus lyngbyaceus mat communities in a semi-eutrophic marine community. Limnology \& Oceanography 35: 1788-1795

Diaz RJ \& Rosenberg R (1995) Marine benthic hypoxia: a review of its ecological effects and the behavioral responses of benthic macrofauna. Oceanography and Marine Biology: An Annual Review 33: 245-303

Diaz RJ, Neubauer RJ, Schaffner LC, Pihl L \& Baden SP (1992) Continuous monitoring of dissolved oxygen in an estuary experiencing periodic hypoxia and the effect of hypoxia on macrobenthos and fish. Science of the Total Environment, Supplement 1992: 1055-1068

Downing, JA (1997) Marine nitrogen: Phosphorus stoichiometry and the global N:P cycle. Biogeochemistry 37: 237-252

Downing JA \& McCauley E (1992) The nitrogen:phosphorus relationship in lakes. Limnol. Oceanogr. 37: 936-945

Downing JA, Osenberg CW \& Sarnelle O (1999) Meta-analysis of marine nutrient-enrichment experiments: variation in the magnitude of nutrient limitation. Ecology 80(4): (in press)

Doyle RD \& Fisher TR (1994) Nitrogen fixation by periphyton and plankton on the Amazon floodplain at Lake Calado. Biogeochemistry 26: 41-66

Eastwood DA \& Pollard HJ (1992) Amazonian colonization in eastern Ecuador: land use conflicts in a planning vacuum. Singapore J. Tropical Geography 13: 103-113

Elser JJ, Chrzanowski TH, Sterner RW \& Mills KH (1998) Stoichiometric constraints on food-web dynamics: a whole-lake experiment on the Canadian Shield. Ecosystems: in press

Elser JJ, Dobberfuhl D, MacKay NA \& Schampel JH (1996) Organism size, life history, and $\mathrm{N}$ :P stoichiometry: towards a unified view of cellular and ecosystem processes. Bioscience 46: 674-684

Elser JJ, Elser MM, MacKay NA \& Carpenter SR (1988) Zooplankton-mediated transitions between $\mathrm{N}$ and P-limited algal growth. Limnol. Oceanogr. 33: 1-14

Elser JJ, Marzolf ER \& Goldman CR. (1990) Phosphorus and nitrogen limitation of phytoplankton in freshwaters of North America: A review and critique of experimental enrichments. Can. J. Fisheries and Aquatic Sci. 47: 1468-1477

Feller IC (1995) Effects of nutrient enrichment on growth and herbivory of dwarf red mangrove (Rhizophora mangle). Ecological Monographs 65: 477--505

Fernandez ECM, Biot X, Castilla C, Canto AC, Matos JC, Garcia S, Perin R \& Wanderli E (1997) The impact of selective logging and forest conversion for subsistence agriculture and pastures on terrestrial nutrient dynamics in the Amazon. Ciencia e Cultura, in press

Fisher TR, Lesack LFW \& Smith LK (1991) Input, recycling, and export of N and P on the Amazon floodplain at Lake Calado. In: Tiessen H, Lopez-Hernandez D \& Salcedo IH (Eds), Phosphorus Cycles in Terrestrial and Aquatic Ecosystems. Regional Workshop 3: South and Central America (pp 34-53). University of Saskatchewan Press, Regina 
Fleisher S \& Stibe L (1991) Drainage basin management - reducing river transported nitrogen. Verh. Internat. Verein. Limnol. 24: 1753-1755

Forsberg BR (1984) Nutrient processing in Amazon floodplain Lakes. Verh. Internat. Verein. Limnol. 22: 1294-1298

Fourqurean JW, Jones RD \& Zieman JC (1993) Processes influencing water column nutrient characteristics and phosphorus limitation of phytoplankton biomass in Florida Bay, FL, U.S.A.: Inferences from spatial distributions. Estuarine Coastal and Shelf Science 36: 295-314

Furch K \& Junk WJ (1993) Seasonal nutrient dynamics in an Amazonian floodplain lake. Arch. Hydrobiol. 128: 277-285

Galloway JN (1989) Atmospheric acidificatioN:Projections for the future. Ambio 16: 161-166

Galloway JN, Levy H \& Kasibhatia PS (1994) Year 2020: Consequences of population growth and development on deposition of oxidized nitrogen. Ambio 23: 120-123

Garrity DP \& Agustin DP (1995) Historical land use evolution in a tropical acid upland agroecosystem. Agriculture, Ecosystems and Environment 53: 83-95

Golterman HL (1975) Physiological Limnology: An Approach to the Physiology of Lake Ecosystems. Elsevier, Amsterdam, The Netherlands

Gonzalez E, Paolini J \& Infante A (1991) Water chemistry, physical features and primary production of phytoplankton in a tropical blackwater reservoir (Embalse de Guri, Venezuela). Verh. Internat. Verein. Limnol. 24: 1477-1481

Hall A, Davies BR \& Valente I (1976) Cabora Bassa: Some preliminary physicochemical and zooplankton pre-impoundment results. Hydrobiologia 50: 17-25

Hall CAS \& Hall MHP (1993) The efficiency of land and energy use in tropical economies and agriculture. Agriculture, Ecosystems and Environment 46: 1-30

Hamilton SK, Sippel SJ, Calheiros DF \& Melack JM (1997) An anoxic event and other biogeochemical effects of the Pantanal wetland on the Paraguay River. Limnology and Oceanography 42: 257-272

Harris GP (1986) Phytoplankton ecology: structure, function and fluctuations. Chapman \& Hall

Hecky RE, Bootsma HA, Mugiddeand RM \& Bugenyi FWB (1996) Phosphorus pumps, nitrogen sinks, and silicon drains: plumbing nutrients in the African Great Lakes. In: Johnson TC \& Odada EO (Eds) Limnology, Climatology and Paleoclimatology of the East African Lakes (pp 205-224). Gordon and Breach, Amsterdam, The Netherlands

Hedgpeth JW (1957) Classification of marine environments. Geological Society of America, Memoir 67, Volume 1: 17-28

Hedin LO, Armesto JJ, \& Johnson AH (1995) Patterns of nutrient loss from unpolluted, oldgrowth temperate forests: evaluation of biogeochemical theory. Ecol. 76: 493-509

Henry R, Tundisi JG \& Curi PR (1984) Effects of phosphorus and nitrogen enrichment on the phytoplankton in a tropical reservoir (Lobo Reservoir, Brazil). Hydrobiologia 118: $177-185$

Hölscher D, Möller RF, Denich M \& Fölster H (1997) Nutrient input-output budget of shifting agriculture in Eastern Amazonia. Nutrient Cycling in Agroecosystems 47: 49-57.

Horne AJ \& Galat DL (1985) Nitrogen fixation in an oligotrophic, saline desert lake: Pyramid Lake, Nevada. Limnol. Oceanogr. 30: 1229-1239

Houghton RA (1994) The worldwide extent of land-use change. BioScience 44: 305-313

Howarth RW (1988) Nutrient limitation of net primary productivity in marine ecosystems. Annual Review of Ecology and Systematics 19: 89-110 
Howarth RW (1998) An assessment of human influences on fluxes of nitrogen from the terrestrial landscape to the estuaries and continental shelves of the North Atlantic Ocean. Nutrient Cycling in Agroecosystems 52: 213-223

Howarth RW, Billen G, Swaney D, Townsend A, Jaworski N, Lajtha K, Downing JA, Elmgren R, Caraco N, Jordan T, Berendse F, Freney J, Kudeyarov V, Murdoch P, Zhao-Liang Z (1996) Regional nitrogen budgets and riverine N \& P fluxes for the drainages to the North Atlantic Ocean: Natural and human influences. Biogeochemistry 35: 75-139

Jaworski NA, Howarth RW \& Hetling LJ (1997) Atmospheric deposition of nitrogen oxides onto the landscape contributes to coastal eutrophication in the northeast United States. Environ. Sci. Technol. 31: 1995-2004

Juo ASR \& Manu A (1996) Chemical dynamics in slash-and-burn agriculture. Agriculture, Ecosystems and Environment 58: 49-60

Justić D, Rabalais NN, Turner RE \& Wiseman WJ Jr (1993) Seasonal coupling between riverborne nutrients, net productivity and hypoxia. Marine Pollution Bulletin 26: 184-189

Kauffman JB, Cummings DL, Ward DE \& Babbitt R. (1995) Fire in the Brazilian Amazon: 1. Biomass, nutrient pools and losses in slashed primary forests. Oecologia. 104: 397-408

Keftasa D (1994) Effects of harvest management and nitrogen application on yield and nutritional value of Rhodes grass and lucerne in pure stands and mixtures. Trop. Agric. 71: 88-94

Kühne RF (1993) Wasser- und Nährstoffhauhalt in Mais-Maniok-Anbausgstemen mit und ohne Integration von Alleekultuven ("Alley cropping") in Süd-Benin. Honen Heimer Bodenkundliche Hefte 13: 1-244

Lesack LFW, Hecky RE \& Melack JM (1984) Transport of carbon, nitrogen phosphorus and major solutes in the Gambia River, West Africa. Limnology \& Oceaonography 29: 816830

Lesack LFW \& Melack JM (1991) The deposition, composition, and potential sources of major ionic solutes in the central Amazon basin. Water Resources Research 27: 2953-2977

Lesack LFW \& Melack JM (1995) Flooding hydrology a mixture dynamics of lake water derived from mutiple sources in an Amazon floodplain lake. Water Resources Research 31: $329-341$

Lesack LFW \& Melack JM (1996) Mass balance of major solutes in a rainforest catchment in the Central Amazon: implications for nutrient budgets in tropical rainforests. Biogeochem. 32: $115-142$

Lesack LFW (1993) Export of nutrients and major ionic solutes from a rain forest catchment in the central Amazon basin. Water Resources Research 29: 743-758

Lewis WM Jr (1981) Precipitation chemistry and nutrient loading by precipitation in a tropical watershed. Water Resources Research 17: 169-181

Lewis WM Jr (1996) Tropical lakes: how latitude makes a difference. In: Schiemer F \& Boland KT (Eds) Perspectives in Tropical Limnology (pp 43-64). SPB Academic Publishing, Amsterdam, The Netherlands

Lewis WM Jr \& Saunders JF (1989) Concentration and transport of dissolved and suspended substances in the Orinoco River. Biogeochemistry 7: 203-240

Lewis WM Jr, Hamilton SK \& Saunders JF (1995) Rivers of northern South America. In: Cushing CE, Cummins KW \& Minshall GW (Eds) River and stream ecosystems. Elsevier, Amsterdam

Loehr RC (1974) Characteristics and comparative magnitude of non-point sources. J. Water Pollution Control Federation 46: 1849-1872 
Mann KH (1975) Relationship between morphometry and biological functioning in three coastal inlets of Nova Scotia. In: Cronin LE (Ed.) Estuarine Research Vol. 1 (pp 634-644). Academic Press, New York, U.S.A.

Margalef R (1971) The pelagic ecosystem of the Caribbean Sea. In: Symposium on Investigations and Resources of the Caribbean Sea and Adjacent Regions (pp 483-489). UNESCO

Matsumura-Tundisi T, Hino K \& Claro SM (1991) Limnological studies at 23 reservoirs in southern part of Brazil. Verh. Internat. Verein. Limnol. 21: 1040-1047

McClain ME, Richey JE \& Pimentel TP (1994) Groundwater nitrogen dynamics at the terrestrial-lotic interface of a small catchment in the Central Amazon Basin. Biogeochemistry $27: 113-127$

McDowell WH \& Asbury CE (1994) Export of carbon, nitrogen and major ions from three tropical montane watersheds. Limnology \& Oceanography 39: 111-125

Melack JM \& Fisher TR (1990) Comparative limnology of tropical floodplain lakes with an emphasis on the central Amazon. Acta Limnologica Brasil 3: $1-48$

Melack JM \& MacIntyre S (1991) Phosphorus concentrations, supply and limitation in tropical African lakes and rivers. In: Tiessen $\mathrm{H}$ \& Frossard E (Eds) Phosphorus Cycles in Terrestrial and Aquatic Ecosystems, Regional Workshop 4: Africa (pp 1-18). Saskatchewan Institute of Pedology

Meybeck M (1982) Carbon, nitrogen, and phosphorus transport by world rivers. American $₫$. Science 282: 401-450

Meybeck M (1998) Man and river interface: multiple impacts on water and particulates chemistry illustrated in the Seine river basin. Hydrobiologia 373: 1-17

Moran MA \& Hodson RE (1994) Dissolved humic substances of vascular plant origin in a coastal marine environment. Limnol. Oceanogr. 39: 762-771

Morris DP \& Lewis WM (1988) Phytoplankton nutrient limitation in Colorado mountain lakes. Freshwater Biol. 20: 315-327

Murdiyarso D \& Wasriin UR (1995) Estimating land use change and carbon release from tropical forests conversion using remote sensing technique. J. Biogeography 22: 715-721

Neill C, Piccolo MC, Steudler PA, Melillo JM, Feigl BJ \& Cerri CC (1995) Nitrogen dynamics in soils of forests and active pastures in the western Brazilian Amazon basin. Soil Biol. Biochem. 27: 1167-1175

Newbold JD, Sweeney BW, Jackson JK \& Kaplan LA. (1995) Concentrations and export of solutes from six mountain streams in northwestern Costa Rica. J. North American Benthological Society 14: 21-37

Odum HT, Copeland BJ \& McMahan E (1972) Coastal Ecosystems of the United States, Vols. 1-4. Conservation Foundation

Ojima DS, Galvin KA \& Turner BL II (1994) The global impact of land-use change. BioScience 44: 300-304

Olsen Y, Jensen A, Reinertsen H, Borsheim KY, Heldal M \& Langeland A (1986) Dependence of the rate of release of phosphorus by zooplankton on the P:C ratio in the food supply, as calculated by a recycling model. Limnol. Oceanogr. 31: 34-44

Pedrozo F \& Bonetto C (1989) Influence of river regulation on nitrogen and phosphorus mass transport in a large South American river. Regulated Rivers: Research \& Management: 4: $59-70$

Pedrozo F, Diaz M \& Bonetto C (1992) Nitrogen and phosphorus in the Parana River floodplain waterbodies. Arch. Hydrobiol./Suppl. 90: 171-185

Peierls BL, Caraco NF, Pace ML \& Cole JJ. (1991) Human influence on river nitrogen. Nature 350: $386-387$ 
Peterjohn WT \& Correll DL (1984) Nutrient dynamics in an agricultural watershed: observations on the role of a riparian forest. Ecological Society of America 65: 1466-1475

Pinay G \& Décamps H (1988) The role of riparian woods in regulating nitrogen fluxes between alluvial aquifer and surface water: A conceptual model. Regulated Rivers: Research and Management 2: 507-516

Portnoy JW (1990) Gull contribution of phosphorus and nitrogen to a Cape Cod kettle pond. Hydrobiologia 202: 61-69

Poss R \& Sargoni H (1992) Leaching nitrate, calcium and magnesium under maize cultivation on anoxisol in Togo. Fert. Res. 33: 123-133

Prospero JM, Barrett K, Church T, Dentener F, Dunce RA, Galloway JN, Levy II H, Moody J \& QuinnP (1996) Atmospheric deposition of nutrients to the North Atlantic Basin. Biogeochemistry 35: 27-73

Quirós R (1990) The Paraná River basin development and the changes in the Lower Basin fisheries. Interciencia 15: 442-451

Rai \& Hill (1980)

Redfield AC (1934) On the proportions of organic derivatives in sea water and their relation to the composition of plankton. In: James Johnstone Memorial Volume (pp 169-192). Univ. Press, Liverpool, England

Rivera-Monroy VH \& Twilley RR (1996) The relative role of denitrification an immobilization in the fate of inorganic nitrogen in mangrove sediments (Terminicos Lagoon, Mexico). Limnol. Oceanogr. 41: 284-296

Rojas Galaviz JL, Vera F, Yanez-Arancibia A \& Day JW (1992) Estuarine primary producers: the Terminos Lagoon a case study. In: Seeliger U (Ed.) Coastal Plant Communities of Latin America (pp 141-154). Academic Press, NY, U.S.A.

Ross MR (1997) Fisheries Conservation and Management. Prentice Hall, Upper Saddle River, NJ, U.S.A.

Rudel T \& Roper J (1996) Regional patterns and historical trends in tropical deforestation, 1976-1990: a qualitative comparative analysis. Ambio 25: 160-166

Saijo Y, Mitamura O, Hino K, Ikusima I, Tunidsi JG, Matsumura-Tundisi T, Sunaga T, Nakamoto N, Fukuhara H, Barbosa FAR, Henry R \& Silva VP (1997) Physiochemical features of rivers and lakes in Pantanal wetland. Jpn. J. Limnol. 58: 69-82

Salas HJ \& Martino P (1991) A simplified phosphorus trophic state model for warm-water tropical lakes. Water Research 3: 341-350

Salati E, Sylvester-Bradley R \& Victoria RL (1982) Regional gains and losses of nitrogen in the Amazon Basin. Plant and Soil 67: 367-376

Salati E, Victoria RL, Martinelli LA \& Richey JE (1991) Forests: their role in global change, with special reference to the Brazilian Amazon. In: Climate Change: Science, Impacts and Policy: Proceedings of the Second World Climate Conference (pp 391-395)

Saunders JF \& Lewis WM Jr. (1988) Transport of phosphorus, nitrogen, and carbon by the Apure River, Venezuela. Biogeochemistry 5: 323-342

Seeliger U (1992) Coastal Plant Communities of Latin America. Academic Press, New York, U.S.A.

Seitzinger SP (1988) Denitrification in freshwater and coastal marine ecosystems: ecological and geochemical significance. Limnol. Oceanogr. 33: 702-724

Setaro FV \& Melack JM (1984) Responses of phytoplankton to experimental nutrient enrichment in an amazon flood plain lake. Limnol. Oceanogr. 29: 972-984

Seyfried MS \& Rao PSC (1991) Nutrient leaching loss from two contrasting cropping systems in the humid tropics. Trop. Agric. 68: 9-18 
Short FT, Davis MW, Gibson RA \& Zimmermann CF (1985) Evidence for phosphorus limitation in carbonate sediments of the seagrass syringodium filiforme. Estuarine, Coastal and Shelf Science 20: 419-430

Shukla J, Nobre C \& Sellers P (1990) Amazon deforestation and climate change. Science 247: 1322-1325

Sjodin A, Lewis WM Jr \& Saunders JF (1997) Denitrification as a component of the nitrogen budget for a large plains river. Biogeochem. 39: 327-342

Skole DL, Chomentowski WH, Salas WA \& Nobre AD (1994) Physical and human dimensions of deforestation in Amazonia. BioScience 44: 314-324

Smith SV (1984) Phosphorus versus nitrogen limitation in the marine environment. Limnology and Oceanography 29: 1149-1160

Søballe DM \& Kimmel BL. (1987) A large-scale comparison of factors influencing phytoplankton abundance in rivers, lakes, and impoundments. Ecology 68: 1943-1954

Soto D \& Stackner J (1996) Oligotrophic lakes in southern Chile and in British Columbia: Basis for their resilience to present and future disturbances. In: Lawford, Alaback \& Fuentes (Eds) High Latitude Rain Forest of the West Coast of the Americas. Climate, Hydrology, Ecology and Conservation (pp 266-280). Springer, NY, U.S.A.

Sterner RW (1990) The ratio of nitrogen to phosphorus resupplied by herbivores: zooplankton and the algal competitive arena. Am. Nat. 136: 209-229

Sterner RW \& Hessen DO (1994) Algal nutrient limitation and the nutrition of aquatic herbivores. Ann. Rev. Ecol. Syst. 25: 1-29

Sterner RW, Elser JJ, Fee EJ, Guildford SJ \& Chrzanowski TH (1997) The light:mutrient ratio in lakes: the balance of energy and materials affects ecosystem structure and function. Am. Nat. 150: 663-684

Sterner RW, Hagemeier DD, Smith WL \& Smith RF (1993) Phytoplankton nutrient limitation and food quality for Daphnia. Limnol. Oceanogr. 38: 857-871

Sur HS, Mastana PS \& Hadda MS (1992) Effect of rates and modes of mulch application on runoff, sediment and nitrogen loss on cropped and uncropped fields. Trop. Agric. 69: 319-322

Sussman RW, Green GM \& Sussman LK (1994) Satellite Imagery, Human Ecology, Anthropology, and Deforestation in Madagascar. Human Ecology 22: 333-349

Teixeira C \& Tundisi JG (1981) The effects of nitrogen and phosphorus enrichments on phytoplankton in the region of Ubatuba, Brazil. Bolm Inst. Oceanogr. 30: 77-86

Thom BG (1982) Mangrove ecology - a geomorphological perspective. In: Clough BF (Ed.) Mangrove Ecosystems in Australia (pp 3-17). Australian National University Press, Canberra

Tilman D (1982) Resource Competition and Community Structure. Princeton University Press, Princeton, NJ, U.S.A.

Tundisi JG (1981) Typology of reservoirs in southern Brazil. Verh. Internat. Verein. Limnol. 21: 1031-1039

Tundisi JG (1987) Local community involvement in environmental planning an management: the Lobo-Broa Reservoir case study. Regional Development Dialogue 8: 133-142

Tundisi JG (1994) Tropical South America: present and perspectives. In: R Margalef (Ed.) Limnology Now: A Paradigm of Planetary Problems (pp 353-424). Elsevier Science, The Netherlands

Tundisi JG \& Matsumura-Tundisi T (1984) Comparative limnological studies at three lakes in tropical Brazil. Verh. Internat. Verein. Limnol. 22: 1310-1314 
Tundisi JG, Matsumura-Tundisi T, Calijuri MC \& Novo EML (1991) Comparative limnology of five reservoirs in the Middle Tietê River, S. Paulo State. Verh. Internat. Verein. Limnol. 24: $1489-1496$

Turner RE \& Rabalais NN (1991) Changes in Mississippi River water quality this century implications for coastal food webs. BioScience 41: 140-147

Twilley RR (1995) Properties of mangrove ecosystems related to the energy signature of coastal environments. In: Hall CAS (Ed.) Maximum Power: The Ideas and Applications of H. T. Odum (pp 43-62). University Press of Colorado, Niwot, CO, U.S.A.

Twilley RR \& Day JW (1998) The productivity and nutrient cycling of mangrove ecosystem. In: Yanez-Arancibia A \& Lara-Dominguez AL (Eds) Mangrove Ecosystems in Tropical America: Structure, Function, and Management (pp 131-156). EPOMEX Scientific Series 3, University of Campeche, Mexico

Uhl C \& Jordan CF (1984) Succession and nutrient dynamics following forest cutting and burning in Amazonia. Ecology 65: 1476-1490

Urabe J, Nakanishi M \& Kawabata K (1995) Contribution of metazoan plankton to the cycling of $N$ and $P$ in Lake Biwa. Limnol. Oceanogr. 40: 232-241

Uttormark PD, Chapin JD \& Green KM (1974) Estimating nutrient loadings of lakes from non-point sources. United States Environmental Protection Agency Report EPA-660/374-020, Washington, DC, U.S.A.

Vallentyne JR (1974) The algal bowl. Canadian Fisheries and Marine Service Miscellaneous Special Publication 22, Ottawa, Canada

Victoria RL, Martinelli, LA, Martatti J \& Richey JE (1991) Mechanisms of water recycling in the Amazon Basin: isotopic insights. Ambio. 20: 384-387

Villar CA, de Cabo L \& Bonetto CA (1996) Macrophytic primary production and nutrient concentrations In: A Deltaic Floodplain Marsh Of The Lower Paraná River. Hydrobiologia 330: $59-66$

Viner AB (1975) The supply of minerals to tropical rivers and lakes (Uganda). In: Hasler AD (Ed.) Coupling of Land and Water Systems (pp 227-261). Springer-Verlag, New York, U.S.A.

Vitousek PM (1984) Litterfall, nutrient cycling, and nutrient limitation in tropical forests. Ecology 65: 1476-1490

Vitousek PM \& Howarth RW (1991) Nitrogen limitation on land and in the sea: How can it occur? Biogeochem. 13: 87-115

Vitousek PM \& Melillo JM (1979) Nitrate losses from disturbed forests: patterns and mechanisms. Forest Sci. 25: 605-619

Vitousek PM, Aber JD \& Tilman DG (1997) Human alteration of the global nitrogen cycle: sources and consequences. Ecological Applications 7: 737-750

Vollenweider RA (1968) Water management research. OECD, Paris, DAS/CSI/68.27

Vorosmarty CJ, Sharma KP, Lough JA (1997) The storage and aging of continental runoff in large reservoir systems of the world. Ambio 26: 210-222

Vought LBM, Dahl J \& Lacoursiere JO (1994) Nutrient retention in riparian ecotones. Ambio 23: $342-359$

Welsh BL, Whitlatch RB \& Bohlen WF (1982) Relationship between physical characteristics and organic carbon sources as a basis for comparing estuarines in southern New England. In: Kennedy VS (Ed.) Estuarine comparisons (pp 53-67). Academic Press, NY, U.S.A.

Williams MR \& Melack JM (1997) Solute export from forested and partially deforested catchments in the central Amazon. Biogeochemistry 38: 67-102

Williams MR, Fisher TR \& Melack JM (1997a) Chemical composition and deposition of rain in the central Amazon, Brazil. Atmosphere \& Environment 31: 207-217 
Williams MR, Fisher TR \& Melack JM (1997b) Solute dynamics in soil water and groundwater in a central Amazon catchment undergoing deforestation. Biogeochemistry, in press

Wollast R, Mackenzie FT \& Chou L (1993) Interactions of C, N, P, and S biogeochemical cycles and global change. NATO ASI series. Series $\mathbb{I}$, Global environmental change. Springer-Verlag, Berlin, Germany

World Resources Institute (1996) World Resources 1996-97. Oxford University Press

Wurtsbaugh WA, Vincent WF, Alfaro Tapia R, Vincent CL, \& Richerson PJ (1985) Nutrient limitation of algal growth and nitrogen fixation in a tropical alpine lake, Lake Titicaca (Peru/Bolivia). Freshwater Biology 15: 185-195

Yanez-Aranciba A (1985) Fish Community Ecology in Estuaries and Coastal Lagoon: Towards an Ecosystem Integration. UNAM-PUAL-ICML Editorial Universitaria, Mexico

Yanez-Aranciba A (1987) Lagunas costeras y estuarios: cronologia, criterios y conceptos para una clasificacion ecologica de sistemas costeros. In: Watanabe S (Ed.) Ecossistemas Coateiros da Costa Sul e Sudeste Brasileira (pp 1-38). Academia de Ciencias, Sao Paulo.

Yanez-Aranciba A \& Lara-Dominguez AL (1998) Mangrove Ecosystems in Tropical America: Structure, Function and Management. EPOMEX Scientific Series 3, University of Campeche, Mexico

Yoshioka P, Owen G \& Pesante D (1985) Spatial and temporal variations in Caribbean zooplankton near Puerto Rico. J. Plankton Research 7: 733-751 